\title{
A preliminary review of the fossil species of Ranina Lamarck, 1801 (Decapoda, Brachyura, Raninidae), with systematic remarks
}

\author{
Giovanni Pasini ${ }^{1}$, Alessandro Garassino ${ }^{2 *}$
}

\begin{abstract}
The systematics of the fossil representatives of Ranina Lamark, 1810, has been discussed by several authors in the last century, showing some problematics above all due to the lack of a close diagnosis of the type species ( $R$. ranina) and to the scarce number of well-preserved type series of each fossil species. However, based upon a close comparison among the type series of each species, authors' original descriptions, and the main diagnostic characters of Ranina, this preliminary review finds that twelve species have to be considered as doubtful species within Ranina, as follows: ?Ranina americana Withers, 1924, ?R. berglundi Squires \& Demetrion, 1992, ?R. bouilleana A. Milne Edwards, 1872, ?R. brevispina Lörenthey, 1898, ?R. granulosa A. Milne Edwards, 1872, ?R. griesbachi Noetling, 1897, ?R. haszlinskyi Reuss, 1859, ?R. libyca (Van Straelen, 1935), ?R. molengraaffi Van Straelen, 1924, ?R. oblonga (von Münster, 1840), ?R. ornata De Angeli \& Beschin, 2011, and ?R. speciosa (von Münster, 1840). Four species have to be considered as Ranina nomina dubia, as follows: Ranina elegans Rathbun, 1945, R. hirsuta (Schafhäutl, 1863), R. lamiensis Rathbun, 1945, and $R$. tejoniana Rathbun, 1926. Ranina bavarica Ebert, 1887, R. fabri Schafhäutl, 1863, and R. helii Schafhäutl, 1863, have to be assigned to Lophoranina Fabiani, 1910. Ranina cuspidata Guppy, 1909, has to be assigned to Calappa Weber, 1795 (Calappidae De Haan, 1833). Finally, R. burleighensis Holland in Holland \& Cvancara, 1958, has to be considered as doubtful species within Decapoda.
\end{abstract}

Key words: Decapoda, Brachyura, Raninidae, Ranina.

Riassunto - Revisione preliminare delle specie fossili di Ranina Lamarck, 1801 (Decapoda, Brachyura, Raninidae), con osservazioni sistematiche.

La sistematica dei rappresentanti fossili di Ranina Lamark, 1810 è stata discussa da numerosi autori nell'ultimo secolo, mettendo in evidenza alcuni problemi dovuti alla mancanza di una approfondita diagnosi della specie tipo (R. ranina) e alla scarsità e povera conservazione degli esemplari originali di ciascuna specie fossile. Tuttavia, grazie ad un confronto tra gli esemplari originali di ciascuna specie, le loro descrizioni originali e i principali caratteri diagnostici di Ranina, questa

${ }^{1}$ Via Alessandro Volta 16, 22070 Appiano Gentile (CO), Italia. E-mail: juanaldopasini@tiscali.it

2 Sezione di Paleontologia degli Invertebrati, Museo di Storia Naturale, Corso Venezia 55, 20121 Milano, Italia.

* Corresponding author: alessandro.garassino@comune.milano.it; alegarassino@gmail.com

(C) 2017 Giovanni Pasini, Alessandro Garassino

Received: 10 October 2016

Accepted for publication: 12 February 2017 revisione preliminare ha permesso di stabilire che dodici specie sono da considerarsi specie dubbie di Ranina: ?Ranina americana Withers, 1924, ?R. berglundi Squires \& Demetrion, 1992, ?R. bouilleana A. Milne Edwards, 1872, ?R. brevispina Lörenthey, 1898, ?R. granulosa A. Milne Edwards, 1872, ?R. griesbachi Noetling, 1897, ?R. haszlinskyi Reuss, 1859, ?R. libyca (Van Straelen, 1935), ?R. molengraaffi Van Straelen, 1924, ?R. oblonga (von Münster, 1840), ?R. ornata De Angeli \& Beschin, 2011 e ?R. speciosa (von Münster, 1840). Quattro specie sono da considerarsi come Ranina nomina dubia: Ranina elegans Rathbun, 1945, R. hirsuta (Schafhäutl, 1863), R. lamiensis Rathbun, 1945 e R. tejoniana Rathbun, 1926. Ranina bavarica Ebert, 1887, R. fabri Schafhäutl, 1863 e $R$. helii Schafhäutl, 1863 devono essere attribuite a Lophoranina Fabiani, 1910. Ranina cuspidata Guppy, 1909 deve essere attribuita a Calappa Weber, 1795 (Calappidae De Haan, 1833). Infine R. burleighensis Holland in Holland \& Cvancara, 1958 deve essere considerata una specie dubbia nell'ambito dei Decapoda.

Parole chiave: Decapoda, Brachyura, Raninidae, Ranina.

\section{INTRODUCTION}

The morphological characters and systematics of the extant and fossils Raninidae De Haan, 1839 were previously discussed by several authors (Tucker, 1988; Guinot, 1993; Ahyong et al., 2007; Feldmann \& Schweitzer, 2007). Later Karasawa et al. (2011) provided a cladistic analysis of fossil and extant Raninoida representatives, whereas Van Bakel et al. (2012) provided an emended diagnosis of the family. Finally, Karasawa et al. (2014) proposed a phylogenetic hypothesis and new re-classification of the section.

Moreover, Karasawa et al. (2014: 260) also provides a diagnosis of Ranina, based on the extant and fossil type species $R$. ranina: "Carapace generally widest in anterior one-quarter, narrowing posteriorly; rostrum trifid, with axial two spines serving as inner orbital spines, central spine triangular; intra- and outer orbital spines triangular; anterolateral margin generally with two spines that are bifid or trifid, often larger and more complexly ornamented in males; post-frontal region depressed slightly below level of remainder of carapace, can be granular or scabrous; remainder of carapace ornamented with forward directed spines; appendages and pterygstome ornamented with less densely-spaced spines; sternum smooth."

Due to the lack of a close diagnosis of the type species (D. Guinot pers. comm., 2014; J. Luque pers. comm., 2016), and based on the more recent diagnosis by Karasawa et al. (2014), we focused our attention on the main diagno- 
stic characters of the carapace more commonly preserved in fossil specimens (= 'proxy characters' sensu Schweitzer, 2003): the rostrum outline, the frontal spines, the shape of the anterolateral spines, and the dorsal ornamentation.

Based upon the most recent diagnosis of the genus, the type materials, and authors' original descriptions and figures, we are able to carry on a review of all listed species assigned to Ranina by Karasawa et al. (2014) (23 species) in order to attest or not their assignment to the genus.

We provide for the revised species the author's original descriptions, supplied with their literal translations (never previously proposed), in order to make easier the direct comparison, and useful to follow each discussion.

This preliminary review allows us to consider that twelve species have to be considered as doubtful species within Ranina, as follows: ?Ranina americana Withers, 1924, ?R. berglundi Squires \& Demetrion, 1992, ?R. bouilleana A. Milne Edwards, 1872, ?R. brevispina Lörenthey, 1898, ?R. granulosa A. Milne Edwards, 1872, ?R. griesbachi Noetling, 1897, ?R. haszlinskyi Reuss, 1859, ?R. libyca (Van Straelen, 1935), ?R. molengraaf$f i$ Van Straelen, 1924, ?R. oblonga (von Münster, 1840), ?R. ornata De Angeli \& Beschin, 2011, and ?R. speciosa (von Münster, 1840). Four species have to be considered as Ranina nomina dubia, as follows: Ranina elegans Rathbun, 1945, R. hirsuta (Schafhäutl, 1863), R. lamiensis Rathbun, 1945, and R. tejoniana Rathbun, 1926. Ranina bavarica Ebert, 1887, $R$. fabri Schafhäutl, 1863, and $R$. helii Schafhäutl, 1863, have to be assigned to Lophoranina Fabiani, 1910. Ranina cuspidata Guppy, 1909, has to be assigned to Calappa Weber, 1795 (Calappidae De Haan, 1833). Finally, R. burleighensis Holland in Holland $\&$ Cvancara, 1958, has to be considered as a doubtful species within Decapoda.

After Glaessner (1929), no author has reported in the systematic lists of Ranina species, $R$. fabri and $R$. helii described by Schafhäutl (1863), probably because Glaessner (1929: 361, 362), simply considered both species as synonymous with "Lophoranina marestiana" [= Ranina (Lophoranina) Marestiana, sic], without any discussion to justify this assignment. Therefore, in this review we consider also these "disappeared" species in order to clarify their systematic assignment.

Ranina palmea E. Sismonda, 1846, R. pellattieroi De Angeli \& Beschin, 2011, R. propinqua Ristori, 1891, and $R$. ranina (Linnaeus, 1758), not discussed in this study will be the subject of next review, based upon the close revision of the extant type species $R$. ranina (Luque, work in progress) who will provide a updated diagnosis for the genus. The future revision will be useful to attest if the above-mentioned fossil species, listed as Ranina by Karasawa et al. (2014: 260) have the diagnostic characters to justify their assignment to this genus or if they should be considered as belonging to new taxa within the Raninidae.

\section{Abbreviations}

BSPG: Bayerische Staatssmmlung für Paläontologie und Geologie, Munich (Germany); CASG: California Academy of Sciences, San Francisco (USA); IGM: Co- lección Nacional de Paleontología, Instituto de Geología, UNAM, Mexico City (Mexico); IHNFG: Museo de Paleontología "Eliseo Palacios Aguilera", Instituto de Historia Natural y Ecología de Chiapas, Chiapas (Mexico); MCZ: Museo civico "G. Zannato", Montecchio Maggiore, Vicenza (Italy); MNHM: Muséum national d'Histoire naturelle, Paris (France); NHM: Natural History Museum, London (Great Britain); MHN-UABCS: Museo de Historia Natural, Universidad Autónoma de Baja California Sur, La Paz, Baja California Sur (Mexico); USNM: US National Museum of Natural History, Washington (USA).

\section{SPECIES DOUBTFULLY ATTRIBUTED TO RANINA}

?Ranina americana Withers, 1924

Fig. 1

Ranina americana Withers, 1924: 125-127, Pl. 4, figs. $1-3$.

Ranina americana - Rathbun 1926: 91, Pl. 23, figs. 1-4. - Glaessner 1929: 360. - De Angeli et al. 2009: 120. - Waugh et al. 2009: 20, Tab. 1. - Schweitzer et al. 2010: 74. - De Angeli \& Beschin 2011: 13. - Van Bakel et al. 2012: 208. - Karasawa et al. 2014: 260.

Hela americana - Lörenthey in Lörenthey \& Beurlen 1929: 109.

Type material: holotype, NHM 23798.

Type locality: Clallam Bay, south shore of Strait of Juan de Fuca, Washington State, USA; Blakeley Formation, Late Oligocene.

Geological age: Late Oligocene.

Examined material: holotype; 4 specimens reported by Rathbun (1926) from the middle Eocene Hoko River Formation, Washington State, USA (Stanford University, N. Pac. 167); 3 specimens reported by Karasawa et al. (2014), KSU D675-678, from the the middle Eocene Hoko River Formation, Washington State, USA.

Description by Whiters (1924): "Cephalothorax elongate-ovoid, moderately convex transversely, width of orbito-frontal margin about equal to half that of the carapace; length, imperfect, $60 \mathrm{~mm}$; breadth $48 \mathrm{~mm}$; anterolateral margins with three large lobes, very narrowly and deeply separated; the anterior lobe on the left side is the only one preserved entire, and this has a broadly rounded margin; the middle lobe is of about the same width, but evidently projected beyond the others; the third and posterior lobe being small and projected only to a small extent; the postero-lateral margins converge posteriorly, are slightly raised to form a rim, which is weakly serrated above; the orbito-frontal margins broken away, but on the right side is an impression of the eye-stalk and on the left the eye-stalk itself; outer surface smooth except on the sides of the anterior half of the carapace, where there are semicircular incisione, behind which the surface is raised and the edges slightly toothed; these markings are somewhat coarser anteriorly; on the inner surface only the 

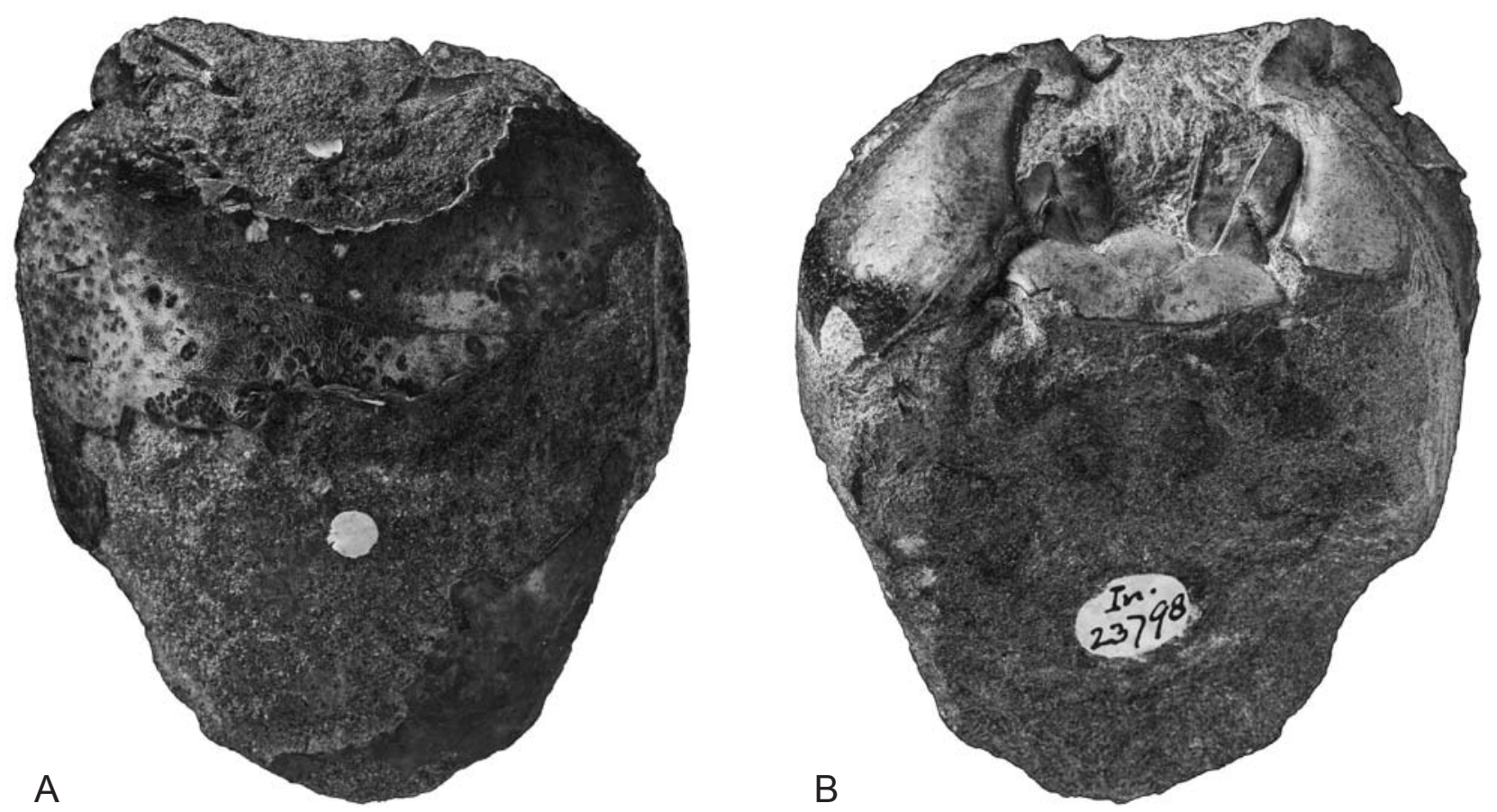

Fig. 1 - ?Ranina americana Whiters, 1924; holotype, NHM 23798. A) Dorsal view. B) Ventral view. (x 1.3).

anterior half of the specimen is preserved, and the pterygostomian plates, the third maxillipedes, and the first sternal plate are displaced; pterygostomian plates extremely convex, with the sides bordering the buccal cavità slightly excavated, and below there is a small rounded excavation for the basal joint of the third maxillipedes; the inner half of the surface is smooth and minutely pitted, and the outer half is coarsely ornamented with raised scale-like markings, toothed on the anterior edge, and these markings become more closely disposed towards the outer margin; third maxillipedes much elongated; first sternite widely trifid, with the outer lobes widely rounded, wider than the middle lobeor episternum; the sides curve downward and become subparallel; surface of first scernite marked by a number of pits, forming an almost symmetrical pattern; episternum with the anterior margins forming an obtuse angle and the posterior margins slightly inclined outwards; branchiostergite with the buccal margin sinuous, obliquely inclined outwards, and the margin adjoining the pterygostomian plate bordered by a close line of pits; the middle of the plate is raised to form a ridge, steep-sided and somewhat concave on the outer side, where there are a number of corse but small scale-like markings; a few similar, but smaller, markings are situated near to the buccal margin."

Discussion. Withers (1924) described $R$. americana from the late Oligocene Blakeley Formation of Clallam Bay, Washington State, USA, based upon a single poorly preserved specimen lacking the frontal margin and the anterolateral spines, the main characters useful for a specific assignment. The correct locality where this specimen was collected is unknown except for Clallam Bay which has exposures from Upper Oligocene to Lower Miocene Clallam Formation (Arnold, 1906; Addicott, 1976; Prothero $\&$ Burns, 2001). The Blakeley Formation is limited to ex- posures west of Seattle, Washington (Prothero \& Nesbitt, 2008). This is the only report of a Ranina crab coming from this formation and area. The sole specimen lacks enough diagnostic characters for assignment to specific level. In conclusion the inability to recognize the diagnostic characters of Ranina questions the placement of americana within this genus.

Rathbun (1926: 91, Pl. 23, figs. 1-4) described four poorly preserved specimens from the Hoko River Formation referring them to $R$. americana. However, as stated above, the type species does not have enough diagnostic features to make a comparison with the other species of Ranina.

Karasawa et al. (2014: 250, fig. 18C) figured a specimen of $R$. americana from the late Eocene Hoko River Formation (KSU D677). This specimen is better preserved than the ones reported by Rathbun (1926) in having a wide, subtriangular first anterolateral spine, a second, directed outward, anterolateral spine with accessorial denticles on anterior edge of the spine, and a dorsal surface ornated by scabrous granules arranged in different ways along the carapace but never forming transverse rims. In addition, Karasawa et al. (2014) also lists three specimens of $R$. americana (KSU D675, D676, D678) without any comparison with the type material. Indeed these specimens cannot be compared with the type material because they do not preserve the anterolateral spines and the frontal margin, main characters necessary to comparisons at specific level in Ranina.

Both specimens referred to $R$. americana by Rathbun (1926) and Karasawa et al. (2014) could be assigned to Raninidae sensu stricto. However, previous authors have not compared these specimens with the holotype or considered the differences in age and formations. Therefore, until new specimens are found preserving specific level characters these specimens should be referred as ?Ranina sp. 
?Ranina berglundi Squires \& Demetrion, 1992

Fig. 2

Ranina berglundi Squires \& Demetrion, 1992: 43, 44, figs. 128, 129.

Ranina berglundi - Schweitzer et al. 2006: 24, 27, 28, figs. 2.5, 2.6. - Vega et al. 2008: 54, Pl. 1, figs. 1315, Pl. 2, figs. 1, 2. - Schweitzer et al. 2010: 74. - De Angeli \& Beschin 2011: 13. - Van Bakel et al. 2012: 208. - Karasawa et al. 2014: 260. 5914

Type material: holotype, IGM 5913; paratype, IGM

Type locality: locality CSUN 1220b; Baja California Sur (Mexico), Bateque Formation.

Geological age: early Eocene.

Examined material: holotype and paratype; three specimens (IHNFG-3013-3015) from the early Eoce-
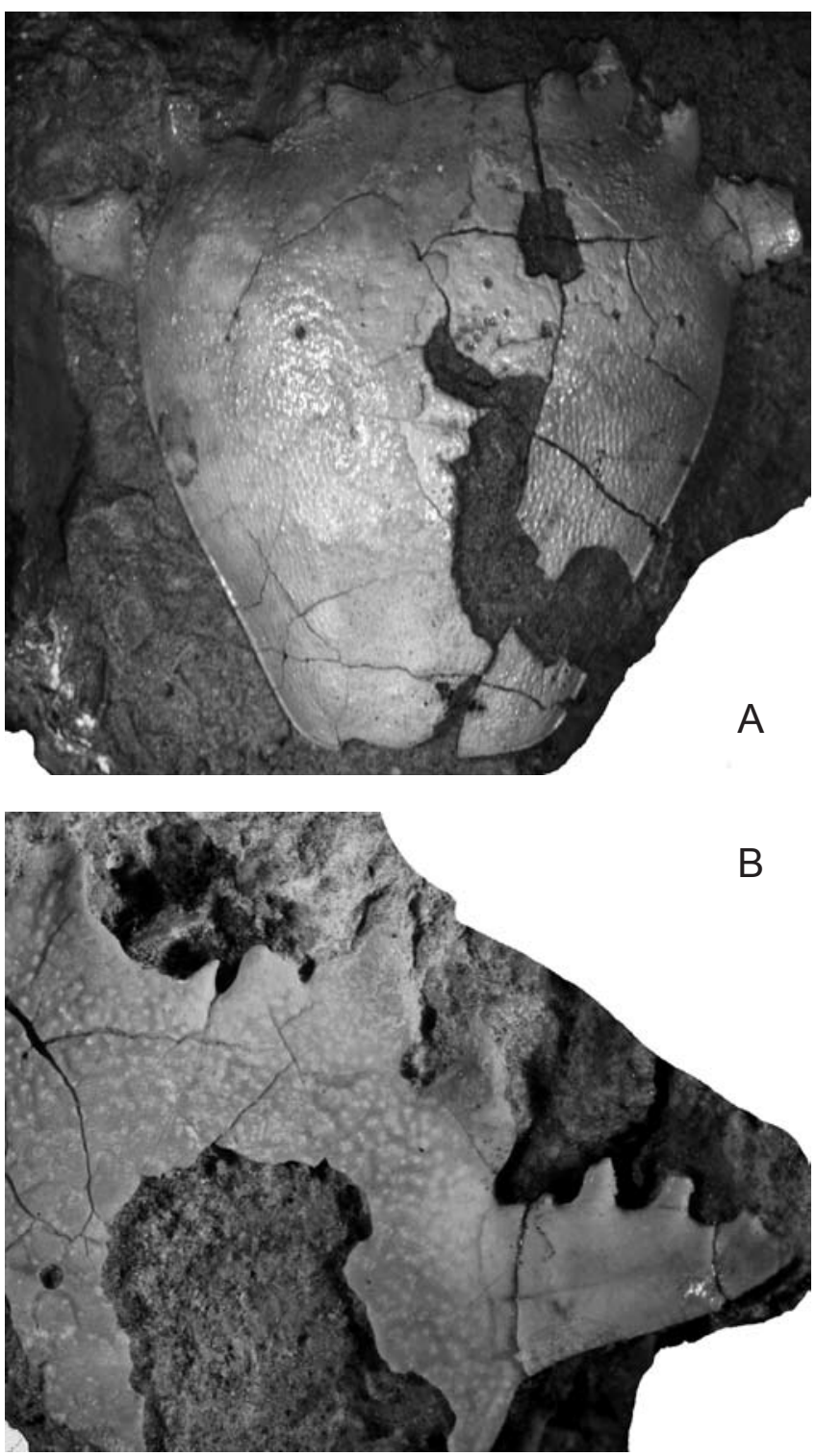

Fig. 2 - ?Ranina berglundi Squires \& Demetrion, 1992. A) holotype, IGM 5913 (x 1.8). B) paratype, IGM 5914 (x 4.5). ne (El Bosque Formation), locality El Veinte (Chiapas, Mexico), reported by Vega et al. (2008); one specimen (MHN-UABCS/Ba7-3) from the middle Eocene (Bateque Formation), locality Waypoint $70\left(26^{\circ} 45.918^{\prime} \mathrm{N}\right.$, $\left.113^{\circ} 0.953^{\prime} \mathrm{W}\right)$ (Baja California Sur, Mexico), reported by Schweitzer et al. (2006).

Description by Squires \& Demetrion (1992): “Moderate-sized raninid with ovate, moderately convex carapace, very broad in proportion to its length; widest along anterior one-fifth at outermost anterolateral spine area; carapace maximum width (including outermost anterolateral spines) equals total length; carapace width (excluding outermost anterolateral spines) 80 percent of total length; lateral borders curve inward, posterior margin very narrow; surface with small pits, sparse on anterior middle part, closer posteriorly and toward lateral and anterior borders; posterolaterally, pits in transverse rows of about 10; rostrum trifid, small, and pointed; fronto-orbital margin curved with three spines on each side; first (innermost) fronto-orbital spine small, outward-pointing, and separated from wider second spine by a short furrow; second fronto-orbital spine separated from forward-pointing and more prominent third spine by a very short and narrow furrow; length of fronto-orbital area about 60 percent of width of carapace (excluding outermost anterolateral spines); two anterolateral spines, equally spaced; first anterolateral spine forward-pointing, about equal in size to outermost fronto-orbital spine, but more pointed; second (outermost) anterolateral spine widest and strongest of all spines, extended at a 45-degree angle to a blunt point, with four serrations on anterior edge of spine (the middle two the strongest); posteriorly to second anterolateral spine, a fine raised rim extends around the carapace; holotype $39 \mathrm{~mm}$ in width (including outermost anterolateral spines), $38 \mathrm{~mm}$ in length."

Discussion. The type material described by Squires \& Demetrion (1992) has trifid rostrum, first anterolateral spine single and second anterolateral spine, strongly directed outward, with four spinules on anterior edge. Schweitzer et al. (2006) assigned six specimens from the Bateque Formation (Baja California Sur) to this species, without adding additional information appreciably to the description of the carapace made by Squires \& Demetrion (1992). Later Vega et al. (2008) assigned tentatively three specimens from Chiapas (Mexico) to this species, pointing out, as difference from the type material, the first anterolateral spine bifid, small size, and distribution of the carapace dorsal pits. However, the review of the type material described by Squires \& Demetrion (1992) allow us to establish that the first anterolateral spine is also bifid, well preserved in the left side of the holotype and slightly broken in the paratype, attesting that the specimens from Baja California Sur (holotype and paratype described by Squires \& Demetrion, 1992) and Chiapas (Schweitzer et al., 2006) could belong to the same species, though the smaller size of Chiapas specimens could be a diagnostic characters to distinguish these specimens from the type material (F.J. Vega pers. comm., 2016).

Based upon the main morphological characters of $R$. berglundi, such as the trifid rostrum and the peculiar sha- 
pe and arrangement of the anterolateral spines (above all the second one), we can attest that these characters do not fit those of Ranina, questioning the placement of berglun$d i$ within this genus.

Indeed $R$. berglundi from the early Eocene of Mexico and the rich sample of specimens from the late Oligocene (Rupelian) of the Ligure-Piemontese Basin (NW Italy) ascribed to $R$. speciosa by Allasinaz (1987) have been assigned to a new genus within the Raninindae sensu stricto (Pasini \& Garassino, 2017).
?Ranina bouilleana A. Milne Edwards, 1872

Fig. 3

Ranina bouilleana A. Milne Edwards, 1872: 6, 9, P1. 8, figs. 2, 2a-c.

Ranina bouilleana - A. Milne Edwards 1873: 8, Pl. 4, fig. 55. - Bittner 1883: 303, 304. - Fabiani 1910: 90, 91. - Glaessner 1929: 361. - De Angeli \& Beschin 2001: 20. - De Angeli et al. 2009: 120, 121. - Schweitzer et
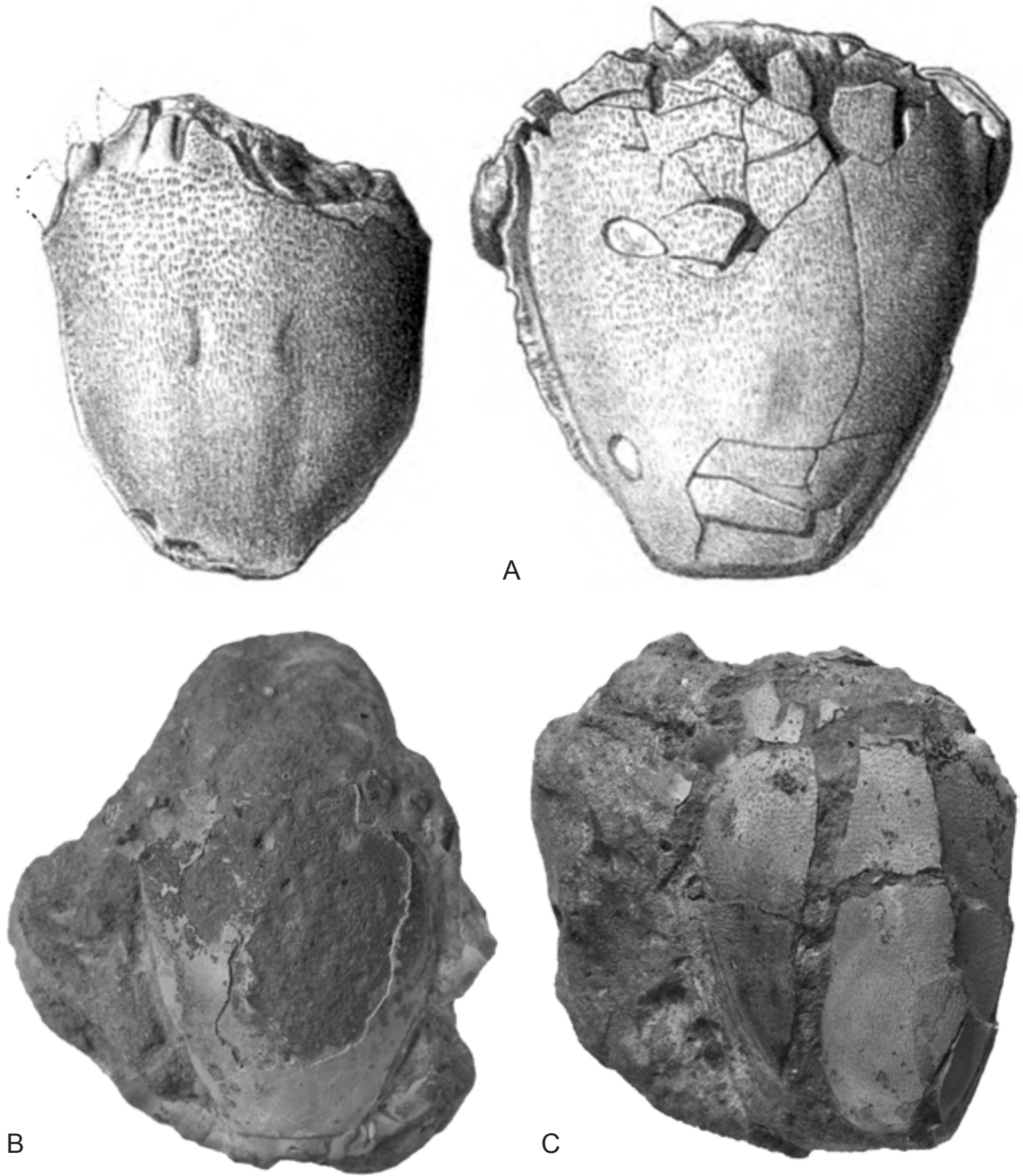

Fig. 3 - ?Ranina bouilleana A. Milne Edwards, 1872. A) Milne Edwards's original figures (Pl. 8, figs. 2, 2a-c). B-C) Two specimens, MNHM R03540, collected from the same locality (Phare de Biarritz) of the type series (natural size). 
al. 2010: 74. - De Angeli \& Beschin 2011: 13, 15, 16, Tab. 1. - Van Bakel et al. 2012: 208. - Karasawa et al. 2014: 260. - Baldanza et al. 2014: 274, 275, fig. 7.

Hela bouilleana - Lörenthey in Lörenthey \& Beurlen 1929: 109.

Type material: lost (S. Charbonnier pers. comm., 2015).

Type locality: Biarritz (Pyrénées Atlantique, Aquitaine, France).

Geological age: "Couches à Nummulites de Biarritz", early Oligocene (SW France); ?early Oligocene (NE Italy).

Examined material: two specimens MNHM R03540 "Coll. Duperier".

Description by A. Milne Edwards (1872): "Plusieurs exemplaires de cette espèce ont été trouvés par M. le comte $R$. de Bouillé aux environs de Biarritz, et je dois à l'obligeance de ce géologue d'avoir pu les étudier et de les décrire; la carapace est moins large que chez R. palmea; cependant, par les progrès du développement, elle s'élargit surtour dans sa portion antérieure; des changements semblables dans les proportions générales du corps s'observent d'ailleurs chez l'espèce des mers de l'Inde, et il suffit, pour s'en convaincre, de jeter les yeux sur les figures que de Haan en a données dans la Fauna japonica; on voit que non-seulement la carapace s'élargit beaucoup en avant chez les vieux individus, mais que les lobes du bord antérieur tendent à se découper et à se digiter de plus en plus, de telle sorte qu'il est impossible d'attribuer une grande importance aux changements de forme que présentent ces parties; de même que chez le $\mathrm{R}$. granulata, le bord latéro-antérieur se découpe en trois lobes grands et très-rapprochés, en dedans desquels existent deux lobes sus-orbitaires plus petits, séparés entre eux par d'étroites scissures; la surface du bouclier céphalothoracique ne porte pas de véritables granulations; elle est au contraire comme corrodée, et l'on y remarque une infinité de petites dépressions ovalaires, souvent rapprochées par groupes de deux ou trois, et plus espacées en avant que sur les parties postérieures et latérales; sur les côtés, il esiste una petite crête linéaire très-finement granuleuse; les sillons branchio-cardiaques sont peu profonds, et on ne les aperçoit que parce que, sur ce point, les petites dépressions ovalaires du test disparaissent presque complétement; la face externe du bras des pattes antérieures est couverte d'un certain nombre de crêtes arquées en avant, paralléles et très-finement granuleuses; des ornaments du même genre garnissent l'avant-bras; la main est très-comprimée, très-haute; son bord inférieur est découpé en dents de scie; l'écusson sternal est grand et lisse."

Literal translation: many specimens of this species were found by the count R. de Bouillé in Biarritz area, giving me the opportunity to study them; the carapace is less wide than that of $R$. palmea though wider anteriorly; changes in the body proportions are also observable in the species living in the Indian Ocean and to look at de Haan's figures in the Fauna japonica; the carapace is wider frontally in the oldest (mature) individuals in which the frontal lobes split in more and more bifid and serrate accessorial points; as in $R$. granulata, the anterorlateral margin has three big lobes, close each other and two small suborbi- tal lobes, separated by narrow fissures; dorsal surface of carapace with ovoid pits, uniformely arranged along posterior and lateral margins, less anteriorly; lateral margins with a granulate ridge; shallow branchiocardiac grooves; outer surface of cheliped with transverse granulate ridges curved forward; carpus with transverse granulate ridges; propodus very flat with serrate inferior margin; wide and smooth sternum.

Discussion. The type series described and figured by A. Milne Edwards (1872) probably housed in the Muséum national d'Histoire naturelle in Paris (France) is today lost. These specimens were very poorly preserved frontally with both the anterolateral spines broken, and from the original description and figures it is not possible to recognize adeguate characters to confirm their assignment. Van Bakel et al. (2012: 208) reported a generic Oligocene age for this species, whereas previously Boussac (1911), carried on a palaeostratigraphic study on the" nummulitique de Biarritz" outcrops, assigning the layers preserving the echinoderm Eupatangus ornatus and including the raninid decapods remains, to the early Oligocene.

Only two specimens have been traced in the Paris $\mathrm{Mu}-$ seum collections (MNHM R03540) as belonging to $R$. bouilleana and collected from the same locality (Phare de Biarritz) of the type series. One specimen preserves first and second anterolateral spines (Fig. 3B), important main characters for specific level. The dorsal carapace shape and general ornamentation fit with the original description by A. Milne Edwards (1872). The rostrum is not preserved.

However, as previously pointed out by Pasini, Garassino \& De Angeli in Baldanza et al. (2014: 276), "these specimens cannot be considered as syntypes because the attached label clearly reported Coll. Duperier, whereas the type specimens had been collected by the Count $R$. de Bouillé,, as attested by A. Milne Edwards (1872: 6). Moreover it's also impossible to establish a lectotype for the poorly preserved front and anterolateral margins of the type series. In conclusion the inability to recognize the diagnostic characters of Ranina questions the placement of bouilleana within this genus.

The two specimens from Duperier's collection were partially discussed by Pasini \& Garassino (2017: 92) in order to clarify their assignment. Indeed, the second anterolateral spine shape, strongly directed outward and serrate dorsally, is not a typical character of Ranina, but allows us to assign these specimens only to the Raninidae sensu stricto.

Finally, we were unable to revise the specimen reported by Bittner (1883) from the Oligocene of Vicenza (NE Italy) originally housed in the Geological Museum of the Vienna University, and most probably today lost, for a close comparison.

?Ranina brevispina Lörenthey, 1898 Fig. 4

Ranina brevispina Lörenthey, 1898b: 135-138, Pl. 10, figs. 2, 3, Pl. 11, fig. 1 .

Ranina brevispina - Fabiani 1910: 91, 92. - Glaessner 1929: 361. - De Angeli et al. 2009: 120. - Schweitzer 
et al. 2010: 74. - De Angeli \& Beschin 2011: 13, 15. - Van Bakel et al. 2012: 209. - Karasawa et al. 2014: 260.

Hela brevispina - Lörenthey in Lörenthey \& Beurlen 1929: 109.

Type material: holotype and repository unknown.

Type locality: Beni Chennadha, Algeria.

Geologcal age: Miocene (Langhian).

Examined material: Lőrenthey's original plates.

Description by Lörenthey (1898): "In dem genannten Musem finden sich aus Algier stammene drei Exemplare einer unbestimmten Ranina-Art, welche in den Formenkreis von Ranina speciosa Münst. gehört, doch wie wir sogleich sehen werden, von allen bekannten verwandten Formen, wesentlich abweicht und so eine gut charakterisirte neue Form ist; die Charaktere derselben lassen sich in Folgendes zusammenfassen; des Cephalothorax ist birnförmig, der grösste Breitendurchmesser befindet sich in dem vorderen Drittel der Längslinie und verschmälert sich sowohl gegen vorn als auch hinten nur schwach; von dem grössten Breitenpunkte erfolgt die Verschmälerung nach rückwärts zu plötzlicher als nach vorne; der Rand des Cephalothorax verläuft von hier S-förmig nach hinten, indem er anfangs - im zweiten Drittel der Länge schwach convex, im letzten Drittel aber concav ist, wodurch sich das Schild gegen hinten plötzlicher verschmälert, so dass der Durchmesser im vordren Drittel noch 42 mm, der Hinterland aber schon nur mehr $19 \mathrm{~mm}$ zählt; der Cephalothorax ist in der Richtung des Breitedurchmessers convex, in der Linie der Längenaxe dagegen fällt er langsam nach rückwärts ab, ohne jedoch convex zu werden; der Stirnrand ist in der Mitte breit und zeigt ei-

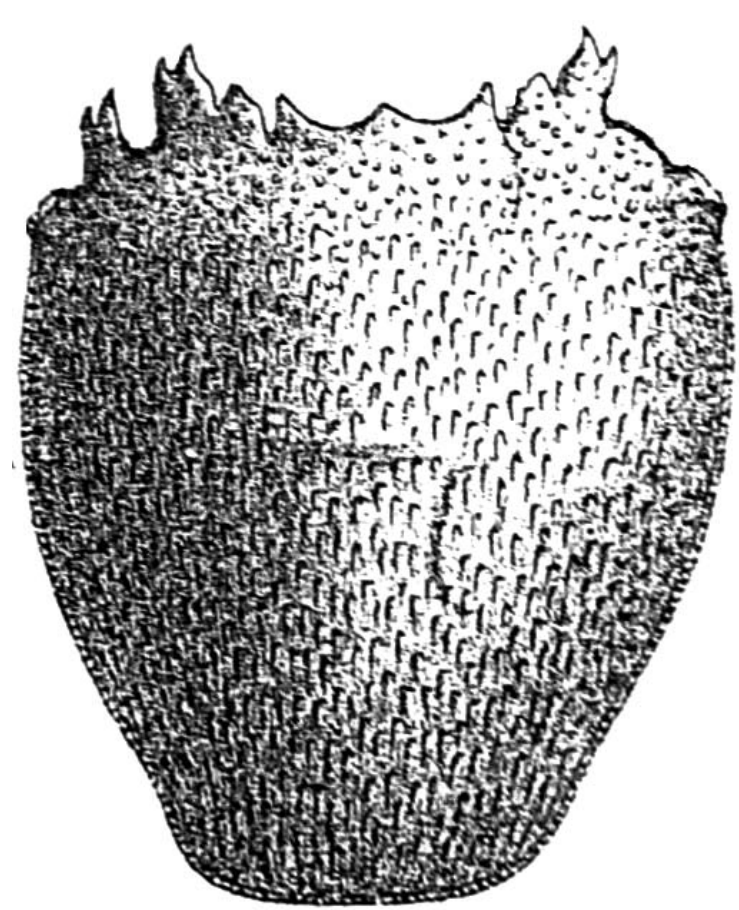

Fig. 4 - ?Ranina brevispina Lőrenthey, 1898; Lőrenthey's original figure (Pl. 10, fig. 2). nen, ein Drittel der Frontalrandbreite einnehmenden Lobus, welcher in drei Spitzen endigt und zwar so, dass die mittlere kürzer und die seitlichen länger sind, die Randkante dagegen ist zwischen den drei Spitzen stark concav; diesel dreispitzige Lobus wird durch je einen schmalen, doch genug tiefen Einschnitt von dem schmalen, zahnartigen, ersten Seitenlobus getrennt, an welchem man, obwohl die Spitze abgebroehen ist, doch gut sehen kann, dass er spitz und mit seiner Spitze gerade nach vorne gerichtet ist; der durch einen viel schwächeren Einschnitt abgetrennte zweite Seitenlobus ist an seinem Ende zweigetheilt und zwar so, dass der innere der beiden Zähne der stärkere ist, während übrigens beide mit ihrer Spitze schwach gegen die Mittellinie zu neigen; nach diesel Lobus folgt ein breiter, und tiefer als der erste reichender Einschnitt, (welcher auf Fig. 2 nicht genug gut dargestellt ist); nach demselben kommt wieder ein, in zwei Zähnen endender Lobus, der dritte Seitenlappen, welcher ähnlich entwickelt, wie der vorige, nur schmäler, kürzer, im Ganzen schwächer ist; der vierte Seitenlobus ist ebenfalls breit und wird durch einen noch weiter nach hinten reicheden Einschnitt von dem Dritten getrennt; er weicht aber in seiner Ausbildung von den anderei dreien ab, da er sich in drei Stacheln theilt, so wie dies auf Fig. 2 und 3 theilweise dargestellt ist, nä mlich der innere Stachel ist stark entwickelt und scharf von dem anderei zweispitzigen Stachel abgesetzt; der innere Stachel dieses zweiendigen Lobus ist schwächer als der äussere; am meisten streckt sich der innere Zahn des zweiten Seitenlobus nach vorne; von hier lässt sich eine gerade Linie bis zu dem mittleren Dorn des mittleren Lappens über den ersten Seitenzahn und die Spitze des Seitenstachels des Mittellobus ziehen; eine andere von dem inneren Zahn des zweiten Seitenlobus über die Spitzen des Zähne bis zur Spitze des äusseren Zahnes des vierten Seitenlobus; der ganze Cephalothorax ist von dem vierten Seitenlobus angefangen nach hinten zu mit einer, mit kleinen Tuberkeln geschmückten Leiste begrenzt, während der mordere Rand vollkommen glatt erscheint; die Oberfläche des Cephalothorax mit Ausnahme des Frontalrandes ist mit länglichen, grossen Tuberkeln bedeckt, zwischen denen hier und dort zerstreut sich kleinere, runde Tuberkel beobachten lassen, deren Zahl gegen die Ränder zu zunimmt; dieselben herrschen dann über der mit Tuberkeln geschmückten Leiste am Rande des Cephalothoax vor; der ganze Stirnrand und dessen Lobi sind mit ebensolchen runden Tuberkeln bedeckt; der untere Theil des Cephalothorax, das Sternum und die Extremitäten konnten wegen ihres mangelhaften Erhaltungszustandes nicht studirt werden; um aber einigermaassen einen Begriff von denselben zu geben, publicire ich in Fig. 1 der Tab. XI. die mangelhafte Unterseite der in Fig. 2 der Tab. X. dargestellten Form, an welcher auch die Eindrücke der Scheerenhände sichtbar sind; die Grösse von Ranina brevispina ist recht variabel; das vollständigste Exemplar (Tab. X. Fig. 2) ist das kleinste."

Literal translation: in the mentioned museum (the Bavarian State Collection in Munich) there are three specimens of an undetermined species of Ranina from Algier, which belongs to the group of Ranina speciosa Münst, but, as we will see below, differs from all previously known related forms and therefore it is a well-defined new form. 
The features of this form are as follows: the cephalothorax is pear-shaped; the maximum width is located in the anterior third and it becomes only gradually taller towards the anterior and posterior parts; from the point of maximum width this narrowing is brusquer towards the posterior part than towards the anterior one; form here the margin is S-shaped; at the beginning - in the second third of the carapace's length - it is weekly convex, in the last third it becomes concave, so that the narrowing of the carapace is brusquer, so that its diameter in the anterior third is $42 \mathrm{~mm}$, but at the posterior margin only 19 $\mathrm{mm}$; the (section of the) cephalothorax is convex in the direction of the width diameter, in its longitudinal axis, however, it gradually slopes down without becoming convex; the frontal margin is broad in the middle and exhibits a lobe, which is one third of the entire frontal margin wide and ends in three spines in that way that the central spine is shorten, whereas the lateral ones are longer, and the marginal edge between these three spines is strongly concave; this three-spined lobe is separated by a narrow, moderately deep incision from the narrow, tooth-like first lateral lobe, at which it is still discernible that it was pointed and the tip was foreward-directed, despite of its broken state; the second lateral lobe, which is separated by a much weaker incision, is bisected at its ending in that way, that the inner one of the two teeth is the stronger one, whereas both are curved pointing with their tips towards the median axis; on the far side of this lobe follows an incision, which is wider and first one (which is not very well illustrated in fig. 2); behind follows again a lobe ending in two teeth, the third lateral lobe, which is similar to the previous one, but narrower, shorter and generally weaker developed; the fourth lateral lobe is broad as well and is separated from the third one by a still deeper incision; it differs from the other three ones by subdividing in three spines, as it is partly shown in figs. 2 and 3, the inner spine is strong and sharply separated from the other bicuspid spine; the inner spine of this twice-ending lobe is weaker than the outer one; the inner tooth of the second lateral lobe is the longest projecting one; it is possible to draw a straight line from here (? the inner tooth) to the middle spine of the middle lappet and the first lateral tooth and the tip of the lateral spine of the median lobe; another one connecting the inner tooth of the second lobe, the tips of the teth and the tip of the outer marginal tooth of the forth lateral lobe; the entire cephalothorax is separated posteriorly by a finely tuberculate crest starting from the forth lateral lobe, whereas the fronal margin appears to be completely smooth; the entire surface of the cephalothorax except of the frontal margin is covered with elongate, large tubercles, between the latter small round tubercles are scattered; their number becomes greater towards the lateral margins, the same tubercles predominate in front of the tuberculate crest at the margin of the cephalothorax; the entire frontal margin and its lobes are covered with the same round tubercles; the ventral part of the cephaolothorax, the sternum and the appendages could not be studied due to the poor preservation state; but to give an impression how they look like I show in fig. 1 of Plate 11 the poor ventral part of the specimen illustrated in fig 2 of Plate 10, in which the imprints of the chelae are visible; the size of Ranina brevispina is variable; the most complete specimen (Plate 10, fig. 2) is the smallest one.

Discussion. The type material, as described and figured by Lörenthey (1898: Pl. 10, fig. 2; Pl. 11, fig. 1) preserves the complete frontal part with the orbital and postorbital spines, triangular rostrum, first anterolateral spine bifid (second one not preserved), typical raninid pleonal sternum shield-like, and shapped and flattened palms of the chelae. Moreover, the general shape and the dorsal granulate ornamentation of the carapace seems typical of Ranina. Though the specimen can be assigned to the Raninidae sensu stricto based upon the above-mentioned characters, the lack of the second anterolateral spine questions its assignment to Ranina.

?Ranina granulosa A. Milne Edwards, 1872

Fig. 5

Ranina granulosa A. Milne Edwards, 1872: 5, 6, Pl. 8, fig. 1 (as granulata [sic] pag. 9 and caption Pl. 8).

Ranina granulosa - Glaessner 1929: 361. - De Angeli et al. 2009: 120. - Schweitzer et al. 2010: 74. - Van Bakel et al. 2012: 209. - Karasawa et al. 2014: 260.

Ranina granulata [sic] - Fabiani 1910: 91. - De Angeli \& Beschin 2011: 13, 15.

Hela granulosa - Lörenthey in Lörenthey \& Beurlen 1929: 109.

Type material: holotype, NHM I8085.

Type locality: unknown (probably Dax, Gironde, southwestern France).

Geological age: Paleogene (Eocene-?Oligocene).

Examined material: holotype.

Description by A. Milne Edwards (1872): "Le bouclier cèphalothoracique de cette espèce est peu èlargi, et sous ce rapport differe beaucoup de celui du Ranina palmea Sism.; le bord antérieur est très-arqué en avant, et porte latéralement trois grosses dents dont on aperçoit la base, mais dont l'extrèmitè est brisée; en dedans de ces dents il existe deux lobes sous-orbitaires, séparés l'un de l'autre et de la dent interne par des scissures étroites et profondes; enfin, le front s'avance sur la ligne médiane en une petite pointe rostrale; la carapace est complétement dépourvue de lignes saillantes granuleuses, transversales et paralléles; on y remarque des tubercules petits, arrondis et disposes sans beucoup d'ordre; en dessous, l'écusson sternal est relativement petit; les pattes-mâchoires externes sont au contraire très-longues; les pattes antérieures et les pattes ambulatoires manquent complétament sur l'exemplaire que j'ai eu les mains."

Literal translation: carapace with maximum widest anteriorly; anterior margin convex, bearing two stout incomplete anterolateral teeth of which only the base is preserved; two suborbital lobes, separated each other by the inner tooth and by a deep narrow fissures; a small pointed rostrum is present in the middle of the front; the carapace does not show transverse granulate rims; only 

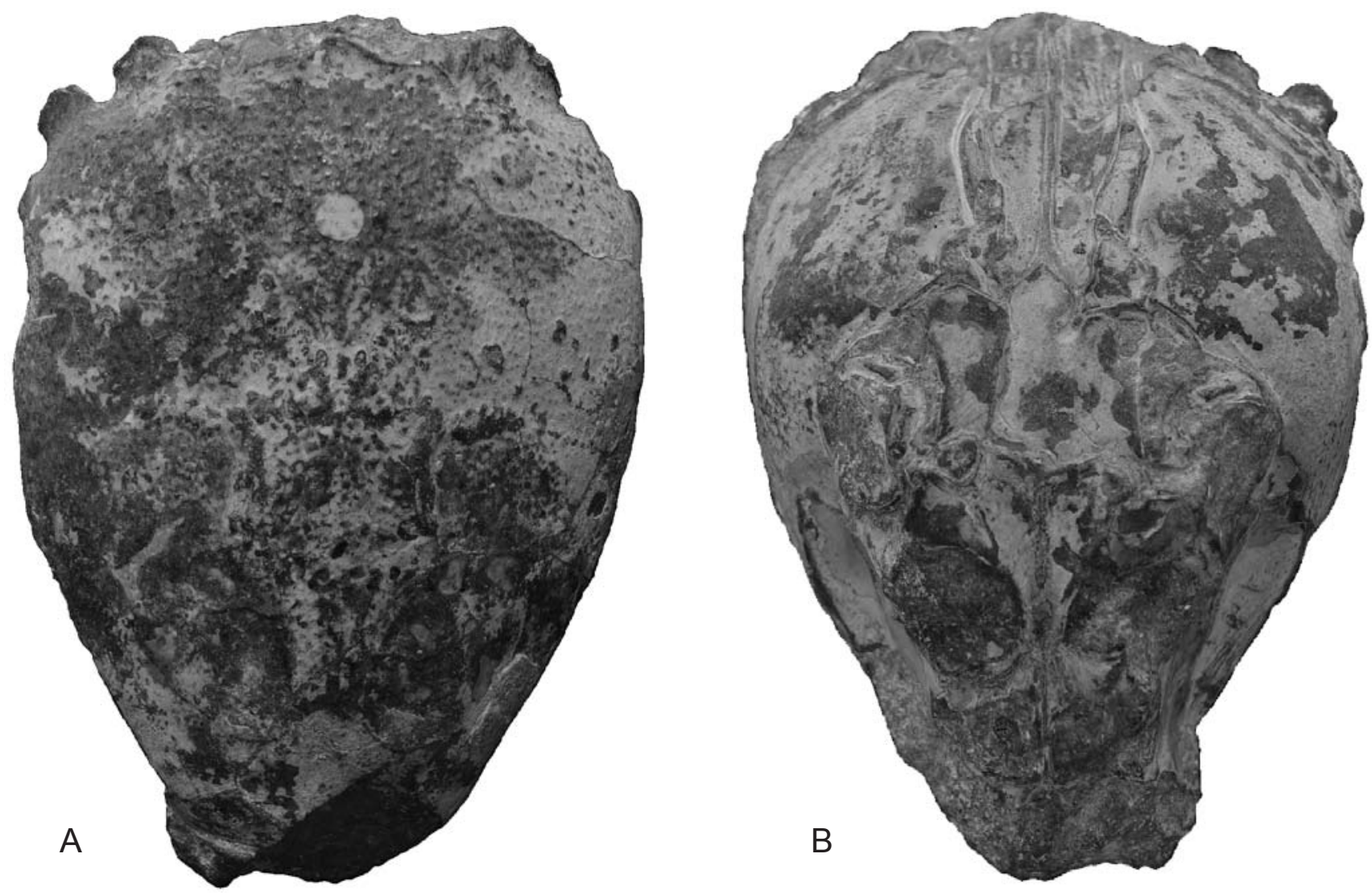

Fig. 5 - ?Ranina granulosa A. Milne Edwards, 1872; holotype, NHM I8085. A) Dorsal view. B) Ventral view. (x 1.1).

small, rounded and sparse tubercles are present, more pronounced frontally; ventrally, the sternum is relatively small; outer maxillipeds very elongate; chelipeds and walking legs not preserved.

Discussion. Based upon the description by A. Milne Edwards (1872), the holotype does not preserve the distal portion of the rostrum and the tips of the anterolateral spines. Though the shape and dorsal ornamentation of the carapace fit the general characters of the Raninidae sensu stricto, the holotype lacks the main characters for its generic assignment. In conclusion, the inability to recognize the diagnostic characters of Ranina questions the placement of granulosa within this genus.

?Ranina griesbachi Noetling, 1897

Fig. 6

Ranina griesbachi Noetling, 1897 Series XVI, Part 3: 78, P1. 22, fig. 4.

Raninella griesbachi - Glaessner 1929: 369. - Schweitzer et al. 2010: 74. - Van Bakel et al. 2012: 209.

Ranina griesbachi - Karasawa et al. 2014: 260.

Type material: holotype and repository unknown.

Type locality: neighborhood of Khattan, Mari Hills beds, Balochistán province (Pakistan).
Geological age: Late Cretaceous (Maastrichtian).

Examined material: Noetling's original plate (1897: Pl. 22, fig. 4).

Description by Noetling (1887): "The greatest breadth of the anterior part, measured between the second lateral spines, is $58 \mathrm{~mm}$; the front margin, taken as a whole from the base of the rostrum to the first lateral spine, is almost straight; the narrow rostrum, which is unfortunately a little damaged, must have been short, apparently three-pointed, and hollowed by a deep but short longitudinal furrow; the orbital margin is indented, at about the

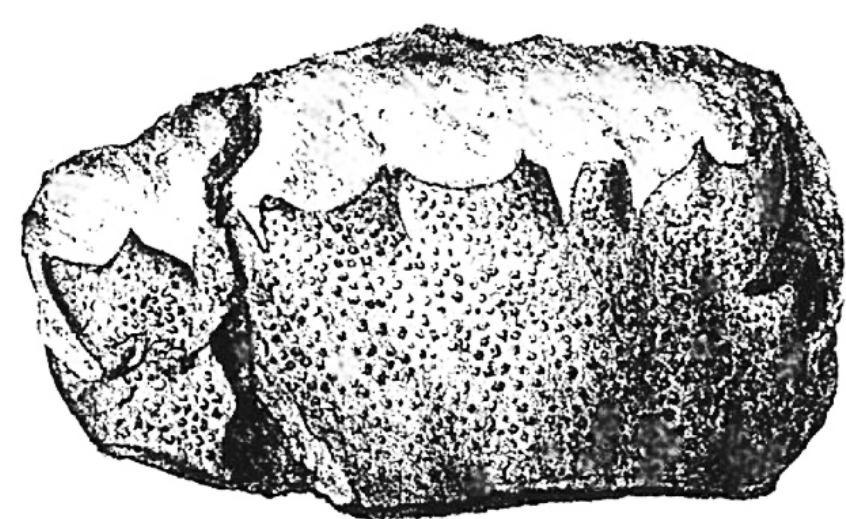

Fig. 6 - ?Ranina griesbachi Noetling, 1897; Noetling's original figure (Pl. 22, fig. 4). 
middle, by two strong incisions, converging in the posterior direction, the outer one of which is slightly longer but narrower than the inner one; between these two incisions the orbital margin forms a broad rounded lobe, provided with a short spine; a similar spine appears at either side of the two incisions; there are three lateral spines, of which the first is broad and long, projecting straight in front; this is separated by a deep and broad incision from the second one, which is narrower and obliquely directed; the latter is separated from the short third antero-lateral spine by a very short incision; the whole surface of the anterior part of the carapace is covered with numerous fine tubercles, which become somewhat coarser in the middle than at the margins; the specimen just shows the first of the fine transverse ridges which cover the posterior part of the carapace, which seems to have been covered also with extremely fine closely set punctures."

Discussion. Noetling (1897: 79) remarks that: "It is possible that the species here described belongs to the genus Raninella, Milne-Edwards, but as the chief distinction of this genus from Ranina consist in the shape of the plastron, which is not visible in the specimen under examination, I refrain from expressing an opinion and take it as belonging to the genus Ranina, to which all the characters of the carapace point." Later this species was assigned by some authors (Glaessner, 1929; Schweitzer et al., 2010; Van Bakel et al., 2012) to Raninella A. Milne Edwards, 1862, perhaps because of its Late Cretaceous geological age (Karasawa et al., 2014: 260). Nevertheless, according to Karasawa et al. (2014: 260), R. griesbachi seems to lack "the narrower fronto-orbital width and postorbital ridge seen in Raninella" (Karasawa et al., 2014: 260). The anterior wide anterolateral margins, wide bifid outer orbital spine, scabrous carapace ornamentation (see Noetling, 1897: Pl. 22, fig. 4), are instead characters of Ranina apart from the suspicious Mesozoic age; for these characters the specimen "can be accommodate in Ranina, which has all these characteristics" (Karasawa et al., 2014: 260). However, in our opinion, the morphological characters observables, such as the deep rostral groove, the presence of a dorsal "fine transverse granulate ridge", the absence of both the anterolateral spines and the incompleteness of the specimen question the placement of this species within Ranina, but not in the Raninidae sensu stricto.

?Ranina haszlinskyi Reuss, 1859

Fig. 7

Ranina haszlinskyi Reuss, 1859: 22, 23, Pl. 4, figs. 4, 5.

Ranina haszlinskyi - A. Milne Edwards 1872: 5. Lörenthey 1898a: 137, Pl. 10, fig. 7 - Oppenheim 1903: 197. - Fabiani 1910: 91. - Glaessner 1929: 362. - De Angeli et al. 2009: 120. - Schweitzer et al. 2010: 74. - De Angeli \& Beschin 2011: 13, 15. - Hyžný 2011: 166. - Van Bakel et al. 2012: 209. - Karasawa et al. 2014: 260.

Hela haszlinszkyi [sic] - Lőrenthey in Lörenthey \& Beurlen 1929: 109, Pl. 4, fig. 13.
Type material: lost (Hyžný pers. comm., 2014).

Type locality: Radatice (=Radács), (eastern Slovakia).

Geological age: early Oligocene (Tomášovce Member of the Borové Formation).

Examined material: Reuss's original plate (1959: Pl. 4, figs. 4, 5).
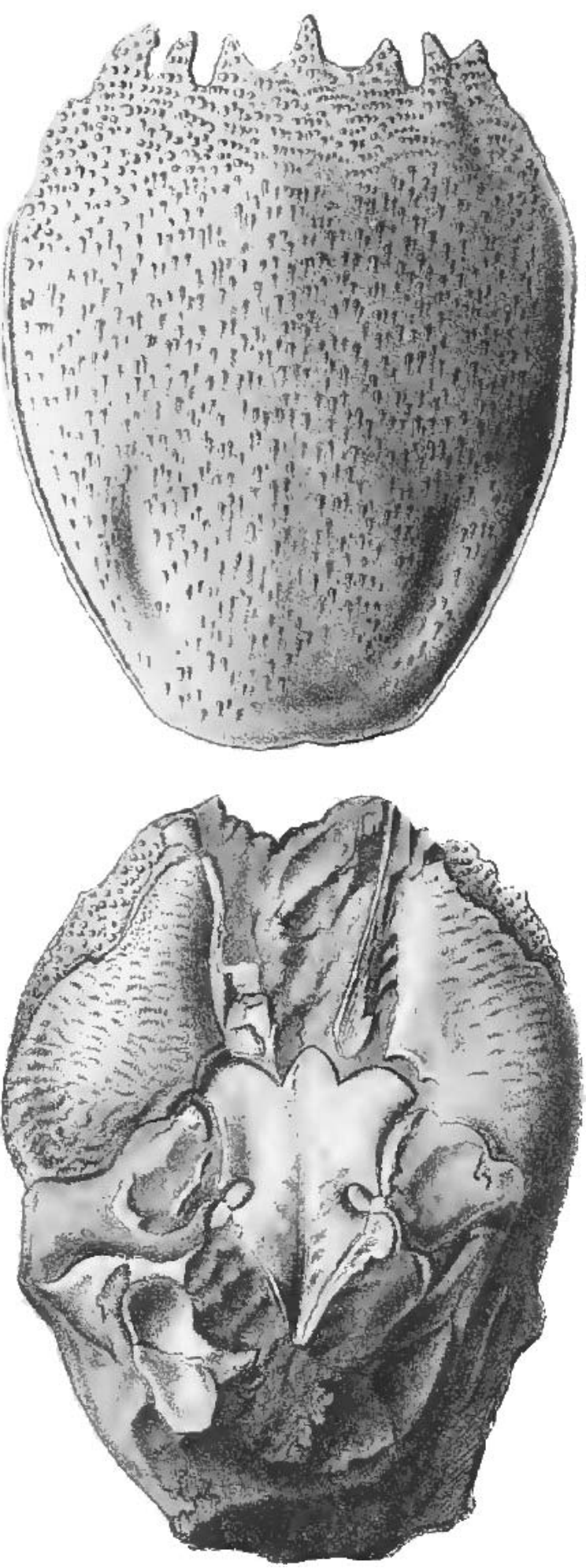

Fig. 7 - ?Ranina haszlinskyi Reuss, 1859; Reuss' original figures (P1. 4, figs. 4, 5). 
Description by Reuss (1859): “Zuletzt muss ich noch eine Ranina-Art besprechen, die mir vom Herrn Professor Haszlinszky in Esperies mitgetheilt wurde; sie stammt aus einem grauen feinkörnigen kalkigen Sandesteine von Iglo bei Eperies, wo sie in Begleitung zahlreicher Exemplare einer Pholadomya und mannigfaltiger Blattreste von Dikotyledonen sehr selten vorkömmt; in der Form des Brustschildes stimmt sie mit R. Aldrovandi Ranz. und R. speciosa v. M. sp., in der Oberflächenbeschaffenheit mit der letztgenannten am meiten überein (Taf. 4, Fig. 4, 5); der nur wenig in der Quere gewölbte Kopfbrustschild ist eiförmig, sich nach hinten allmählich verschmälernd, etwas länger als breit (Länge:Breite=2.75": 2.25 "); bei Ranina Aldrovandi ist nach Desmarest's um ein Viertheil verkleinerter Abbildung das Verhältniss = 2.7": 1.8"; die Seitenränder, deren vorderer Theil an dem einzigen vorliegenden Esemplare abgebrochen ist, sind mit einer schmalen, glatten, erhabenen Leiste eingefasst; der Vorderrand ist leider nur sehr unvollkommen erhalten; doch bemerkt man daran, dass er ebenfalls stark gezähnt gewesen sei; von einem mittleren Zahne, der an unserem Fossilreste an der Basis theilweise losgebrochen ist, wird jederseits durch eine runde Ausbuchtung ein breiter Zahn gesondert, dessen Ende aber abgebrochen scheint; nun folgen nach aussen, durch enge aber tiefe Ausschnitte getrennt, jederseits zwei ebenfalls fragmentäre Zähne, deren äusserer mit dem vorderen Ende einwärts gerichtet ist; der übrige Theil des Vorderrandes ist weggebrochen; die Anordnung der Zähne scheint daher, so weit ein Schluss erlaubt ist, jener bei R. speciosa $v$. M. sehr zu ähneln; der Hinterland ist kurz (0.83"), fast gerade; auch die Oberflächenbeschaffenheit stimmt mit jener von R. speciosa v. M. sehr überein; im vorderen Theile ist die Schale mit gedrängten, aber regellos gestellten, flachen, schuppenartig niedergedrückten, vorwärts gerichteten breiten Höckerchen bedeckt, deren vorderer Rand mit 2-5 knötchenartigen Kerben besetzt ist; im hinteren Theile des Schildes dagegen sind diese Höckerchen viel schmäler und laufen vorne in eine einfache Spitze aus; auch scheinen sie dort nicht so gedrängt zu stehen; das sehr schön erhaltene Sternum hat dieselbe kartenkreuzförmige Gestalt wie das der lebenden Raninen und der R. Aldrovandi; es ist am vorderen Ende am breitesten und dreilappig, an den Seiten eingebogen und verschmälert sich nach hinten, so dass es zwischen dem zweiten und dritten Fusspaare linear wird; in der hinteren Hälfe wird es von einer schmalen Längsfurche durchzogen; im Ganzen ist es grösser als bei R. Aldrovandi; ausserdem bemerkt man an dem in Rede stehenden Fossilreste auf der linken Seite noch einen Theil des schmalen letzten Kieferfusses; jener der rechten Seite ist bis die Basis weggebrochen; ebenso sind nur die Ansatzstellen der Scherenfüsse, so wie des zweiten und dritten Fusspaares wahrzunehmen; von den übrigen Theilen ist eben so wenig als vom Hinterleibe etwas erhalten; Fasst man die angeführten Mzerkmale zusammen, so ergibt sich eine sehr grosse Ähnlichkeit, ja in Beziehung auf die Sculpturverhältnisse der Schale eine vollkommene Übereinstimmung mit Ranina speciosa v. M. sp.; doch wage ich es nicht, unser Fossil damit zu identificiren; es kann dies nur durch die Entdeckung vollständigerer Exemplare, an denen besonders der Vorderrand des Brustschildes conservirt ist, entschieden werden; bis dahin erlaube ich mir dasselbe mit dem $\mathrm{Na}$ men Ranina Haszlinszkyi zu bezeichnen."

Literal translation: at least I will describe a species of Ranina, which I have got from Professor Haszlinszky in Epieries. It comes from a gray fine-grained carbonatic sandstone at Iglo near Eperies, where it rarely occurs together with numerous specimens of a Pholadomya (a bivalve) and diverse dicotyleonean leaf remains. In the shape of the sternum it is close to $R$. aldrovandi Ranz. and $R$. speciosa v. M. sp., in its surface it is closest to the latter (Pl. 4, figs. 4, 5).

The transversely only moderately arched cephalothorax is oval, narrowing gradually towards its posterior end, somewhat longer than wide (length: width $=2.75$ ": 2.25 "); in Ranina aldrovandi this ratio is 2.7 ": 1.8 " following the strongly size-reduced illustration by Desmarest; the lateral margins, the anterior parts of which are broken away in the sole specimen, are bordered by a narrow, smooth, elevated crest. Unfortunately, the frontal margin is only very poorly preserved, but it is discernible that it was strongly dentate as well (as in $R$. aldrovandi); starting from a medium tooth, which is partly broken at its base in our specimen, a broad tooth, the tip of which seems broken, is separated at both sides by rounded lobes; laterally follow two fragmentary teeth, both separated by deep and narrow incisions, the tip of the outer tooth is inwards curved; the rest of the frontal margin is broken off; the arrangement of the teeth seems to be very similar to that in $R$. speciosa v. M.; the posterior margin is short ( 0.83 "), almost straight; the structure of the surface seems to be identical with that in R. speciosa v. M.; in the anterior part the shell is covered with densely but irregular arranged, flattened, scale-like compressed, forward-directed broad cusps, the anterior margin of which bears 2-5 tuberclelike scores; in the posterior part of the carapace these cusps are much narrower and end in a simple tip. In addition, they seem to be less densely arranged in that area; the very well preserved sternum exhibits the same crossshaped habit like in modern raninas and in $R$. aldrovandi; it is broadest in its anterior end and three-lappeted, incised along the margins and narrowing posteriorly, thus becoming straight between the second and third pair of pereiopods. In the posterior half it exhibits a narrow longitudinal furrow; altogether it is bigger than in R. aldrovandi; in addition, on the left side of the studied specimen a part of the narrow last maxillipeds is discernble; on the right side this part is broken off; moreover, only the bases of the chelipeds and of the second and third pereiopods are preserved; the other parts as well as the pleon is not preserved; summarizing all mentioned features there is a very great resemblance, concerning the sculpture of the shell even an identity with $R$. speciosa v. M. sp.; however, I hesitate from identifying the specimen belonging to the latter species; to be sure about this identification, we need more complete material, especially specimens in which the frontal margin of the carapace is preserved; until then, I will name it (tentatively) Ranina haszlinszkyi.

Discussion. In the original and sole specimen described by Reuss (1859) all the frontal teeth are "very poorly pre- 
served, but it is discernible that it was strongly dentate", and the rostrum seems triangular: "a medium tooth, which is partly broken at its base"; whereas both the anterolateral spines are not preserved. The carapace is anteriorly ornamented by granulate transverse crests, whereas dorsally with several sparse pointed spines forward directed. The cardiac region is marked by two deep convex grooves. The sternum shield shows the general shape of Raninidae sensu stricto. Based upon Reuss's description, the sole specimen lacks frontal and anterolateral spines, important characters for its generic assignment. In conclusion, the inability to recognize adequate diagnostic characters of Ranina questions the placement of haszlinskyi within this genus.

Lörenthey \& Beurlen (1929: 3) "noted the late Oligocene age of the specimen, however, the more recent geological survey of the area identified the surrounding of the locality as a part of the exposed Tomášovce Member and yelded the Priabonan - early Oligocene age (predominantly later Priabonian) (Filo \& Stráňová, 1996)" Hyžný (2011).

?Ranina libyca (Van Straelen, 1935)

Fig. 8

Raninella libyca Van Straelen, 1935: 113-115, figs. A-D.

Raninella libyca-Schweitzer et al. 2010: 74.

Ranina libyca - Van Bakel et al. 2012: 209. - Karasawa et al. 2014: 260.

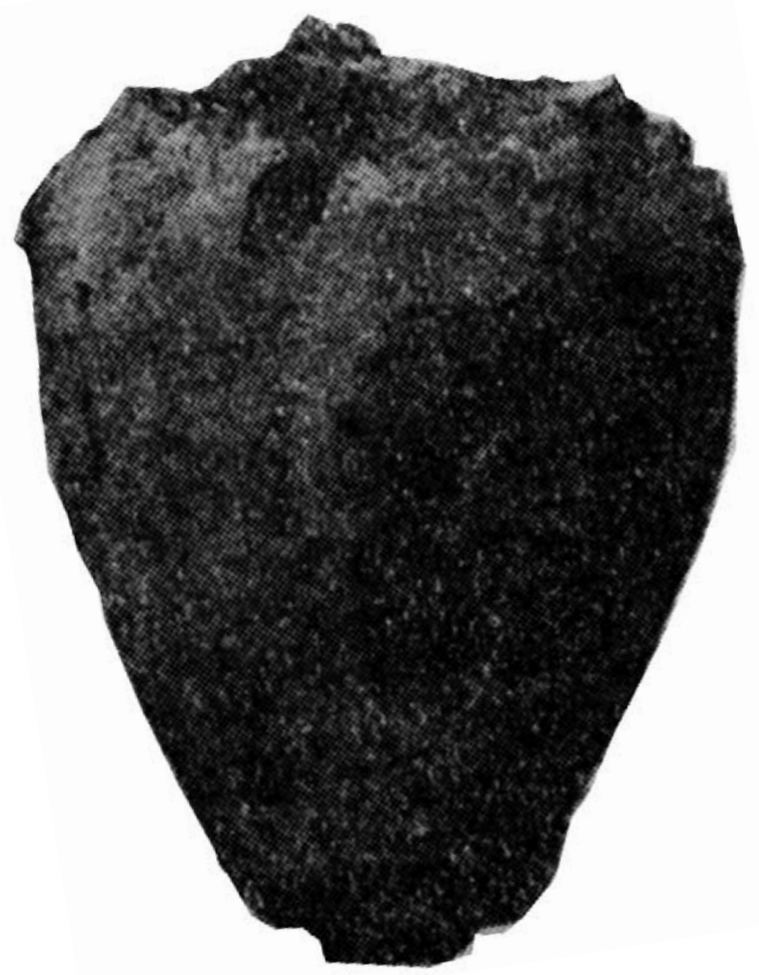

Type material: holotype and repository unknown.

Type locality: Kourkour Oasis, Egypt.

Geological age: Paleocene (Danian).

Examined material: Van Straelen's original figures.

Description by Van Straelen (1935): "L'animal est reduit au céphalothorax; les couches supérieures du test ont été enlevées; la région frontale est fracturée, les épines sont réduites à leur partie proximale; tous les appedices sont détruits, les surfaces d'insertion des peréiopodes ont perdu leur individualité; les plastron sternal est fracturé".

Literal translation: the specimen preserves just the carapace; the specimens appears as inner cast; frontal region poorly preserved; only the proximal part of the spines is preserved; the pereipods are not preserved; sternum poorly preserved.

Discussion. Though poorly preserved, Van Straelen (1935) ascribed the sole specimen to Raninella A. Milne Edwards, 1862, without any justification. Later this assignment was confirmed by Schweitzer et al. (2010: 74). This assignment, however, has been called into question by Van Bakel et al. (2012: 209) who ascribed lybica to Ranina, without any justification, assignment confirmed also by Karasawa et al. (2014: 260). Based upon Van Straelen's description and figures, it is difficult to establish a generic placement for this specimen, lacking all Ranina characters. In conclusion, the inability to recognize the diagnostic characters of Ranina questions the placement of lybica to this genus.

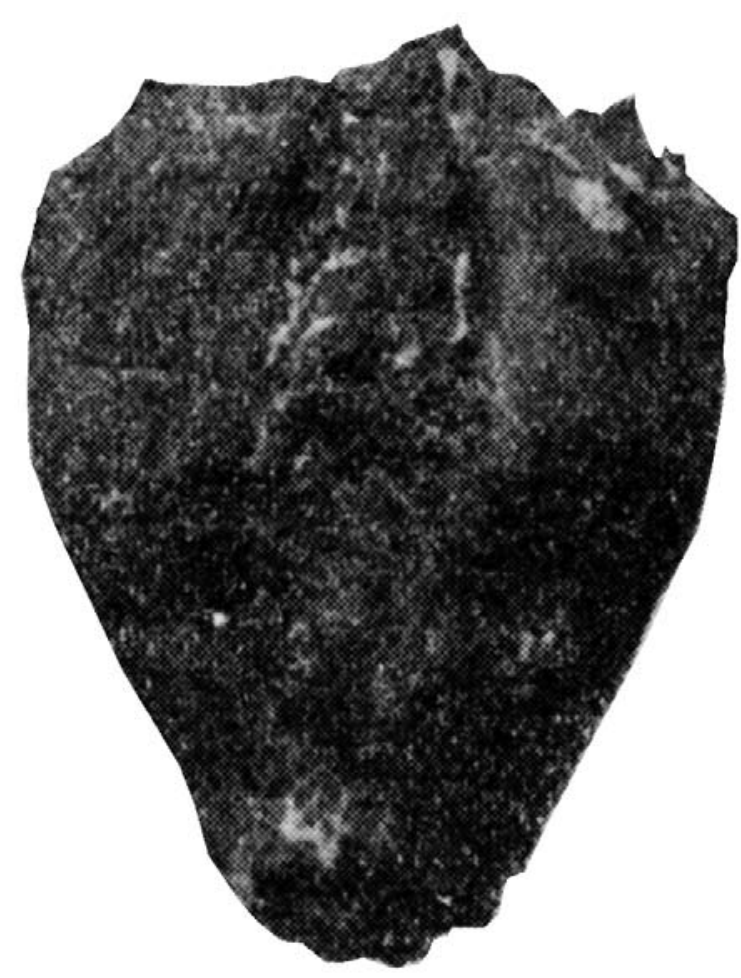

Fig. 8 - ?Ranina libyca (Van Straelen, 1935); Van Straelen's original figures (Figs. C-D). 
?Ranina molengraaffi Van Straelen, 1924

Fig. 9

Ranina (Hela) molengraaffi Van Straelen, 1924: 777, fig. 1a, b.

Ranina molengraaffi - Glaessner 1929: 362. - De Angeli et al. 2009: 120. - Schweitzer et al. 2010: 74. - De Angeli \& Beschin 2011: 13. - Van Bakel et al. 2012: 209. - Karasawa et al. 2014: 45.

Hela molengraaffi - Lőrenthey in Lörenthey \& Beurlen 1929: 109.

Type material: the specimen $\mathrm{N}^{\circ} 6$ of the sample K.A. 6491 was housed in the Geological Museum of the University of Technology in Delft (the Netherlands), but nowadays the KA collection is housed in Leiden in the Naturalis Biodiversity Center (Maaike van Tooren pers. comm., 2016); the fossil crustacean collection of the Naturalis Biodiversity Center won't be available until 2018 and unfortunately Van Straelen's specimen does not appear in the digital records of the invertebrate fossil collection because it is not digitized yet (Natasja den Ouden pers. comm., 2016).

Type locality: Toehoep River Valley (Borneo).

Geological age: Miocene.

Examined material: Van Straelen's original figures.

Description by Van Straelen (1924): “Le céphalothorax dont la longueur dépasse la largeur d'environ 1/5 s'elargit de l'arrière vers l'avant; sa largeur mesurée au niveau de l'insertion des deux dents marginales et celle
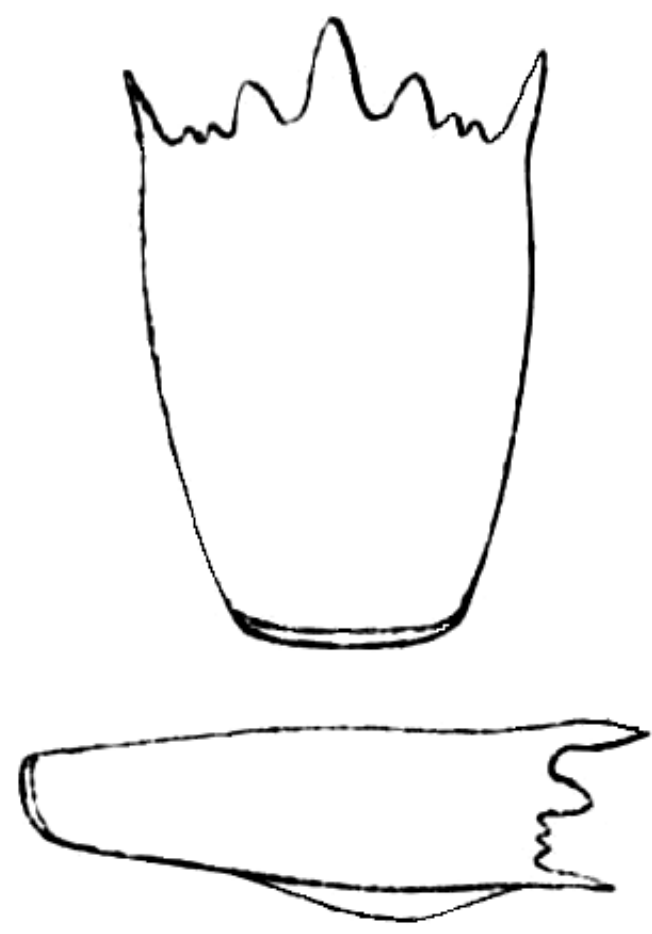

Fig. 9 - ?Ranina molengraaffi Van Straelen, 1924; Van Straelen's original figures (Fig. $1 \mathrm{~A}, \mathrm{~B})$. measurée au bord posterieur, sont dans le rapport de 3 à 2; le céphalothorax est bombé, la courbure s'accentuant dans la region médiane, au point de constituer une crête surbaissée; la region frontale s'incurve vers le haut, de sorte qu'elle semble précedée par une faible depression; une autre depression plus forte que la précédente, exsite dans la region médiane du cephalothorax, au tiers postérieur; la region cardiaque est indiquée par une paire de sillons an arc de cerle, à concavité ouverte vers les bords latéraux; le bord frontal sensiblement rectiligne est occupé par un rostre triangulaire, large et long, bordé par des échancrures oculaires limitées chacune latéralement par un lobe triangulaire à base très large; au delà de ces lobes, se trouvent deux petites épines et enfin une forte dent affilée et incurvée extérieurement, constituant le prologement des bords latéraux; ceux-ci sont un peu incurves et à angle droit avec le bord postérieur; ce dernier est à peu près rectiligne et bordé par un etroit sillon; le test paraissant lisse, est garni de fines granulations, légèrement acuminées, disposées sans ordre apparent. La face sternale n'est pas connue."

Literal translation: carapace longer than wide; carapace convex, mainly in median region, forming a ridge; frontal region curved upward, forming a weak depression; strong depression in median region of carapace; cardiac region marked by two grooves; frontal region with a triangular rostrum wide and long; orbital incisions limited by a triangular lobe laterally; lateral margins with two small spines and one strong outward-directed spine; lateral margin almost straight; posterior margin straight and rimmed; dorsal surface of carapace with granules, slightly pointed, arranged randomly; sternum unknown.

Discussion. Based upon the description of Van Straelen (1924) and relative figures, the species cannot be assigned to Ranina, lacking the diagnostic characters of the carapace of this genus, as remarked by Van Straelen who pointed out also some general affinities with Notopus De Haan 1841, "...for shape and ornamentation of the carapace..." (Van Straelen, 1924: 778). In conclusion, the inability to recognize the diagnostic characters of Ranina questions the placement of molengraaffi within this genus.

?Ranina oblonga (von Münster, 1840)

Fig. 10

Hela oblonga von Münster, 1840: 25, Pl. 2, fig. 4.

Hela oblonga - Reuss 1859: 22. - Lörenthey in Lőrenthey \& Beurlen 1929: 109.

Ranina oblonga - A. Milne Edwards 1872: 5, 9. - Fabiani 1910: 91. - Glaessner 1929: 362. - Lörenthey in Lörenthey \& Beurlen 1929: 103, 104. - De Angeli et al. 2009: 120. - Schweitzer et al. 2010: 74. - De Angeli \& Beschin 2011: 13, 15. - Van Bakel et al. 2012: 209. - Karasawa et al. 2014: 260.

Type material: lost (M. Nose pers. comm., 2014). Type locality: Germany. 
Geological age: Oligocene.

Examined material: Von Münster's original plate (Pl. 2, fig. 4).

Description by von Münster (1840): "Von dieser Art kenne ich erst ein Exemplar, welches im festen Mergel liegt, und von welchem nur der Rückenschild sichtbar ist; dieser unterscheidet sich von der vorigen Art durch seine lange vierseitige Gesalt und bildet ein Oblongura, welches vorn abgerundet und mit sieben starken Zacken besetzt ist, die sämmtlich gezaänt und nach dem mitteren Zacken zu gebegen Sind; die beiden äafsern Zacken sind gabelig; die Oberläche der Schale ist in chen der Art granulirt, wie die vorige Art; das vorliegende Exemplar kommit ebenfalls von Bünde; aufser diesen Brachiuren kommen in den tertiären Meerwasser-Gebilden des nordwestlichen Deutschlands noch andere Arten mit schmalen runden Scheeren und langen dümen Fufspaaren vor; die Bruchstücke meiner Sammlung sind jedoch nicht vollständig genug, um die Geschlechter, zu welchen sie gehören, genan bestimmen zu können."

Literal translation: from this species I know only a single specimen [monotypic holotype!], which is embedded in a hard marlstone and which shows only the dorsal side of the carapace; it differs from the previous species (Hela speciosa) by its long quasi-rectangular shape forming an "oblongum", which is anteriorly (frontally) rounded and bears seven strong teeth, which are all dentate and curved towards the central one; the two outer teeth are bifurcate; the surface of the carapace is grained in the same way as in the previous species; the specimen also comes from Bünde.

Discussion. The general shape of the elongate subrectangular carapace, the narrow front, the shape of the elongate rostrum and anterolateral spines, are typical of the Raninidae sensu stricto, but not of Ranina. In conclusion, the inability to recognize the diagnostic characters of Ranina questions the placement of oblonga to this genus.

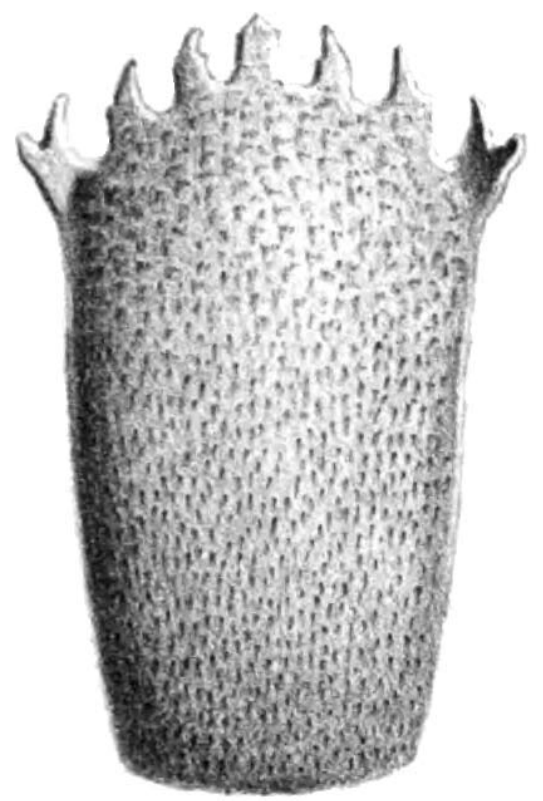

Fig. 10 - ?Ranina oblonga (von Münster, 1840); von Münster's original figure (Pl. 2, fig. 4).
?Ranina ornata De Angeli \& Beschin, 2011

Fig. 11

Ranina ornata De Angeli \& Beschin, 2011: 13-15, fig. 2, Tab. 1.

Ranina ornata - Karasawa et al. 2014: 45, tab. S6. - Baldanza et al. 2014: 276, fig. 8C. - Karasawa et al. 2014: 260. - Famiani et al. 2015: 344.

Type material: holotype, MCZ3391-I.G.336929.

Type locality: Pradipaldo (Marostica, Vicenza, NE Italy).

Geological age: middle Eocene (Lutetian).

Examined material: holotype.

Description by De Angeli \& Beschin (2011): "Carapace a forma di scudo, convesso in senso trasversale, più lungo che largo e maggiormente allargato nella parte anteriore; il margine orbito-frontale occupa l'intera parte anteriore del dorso; il rostro é conservato dalla sola base e i margini sopraorbitali sono incompleti; il dente postorbitale é largo alla base, convesso sul margine esterno, ben proiettato in avanti ed appuntito nella parte distale; i margini antero-laterali sono convessi ed ornate da due denti piatti: il primo dente é subtriangolare, con margine esterno curvo, appuntito distalmente e diretto anteriormente; il secondo dente é piatto, rivolto obliquamente verso l'esterno e suddiviso in tre acute spine sul margine distale; la prima spina é più sottile e di minori dimensioni rispetto alle altre due; i margini postero-laterali sono leggermente curvi, convergenti al margine posteriore ed ornate da una cresta granulata; il margine posteriore si mostra rettilineo nella parte mediana e convesso e carenato superficialmente ai lati; le regioni dorsali non sono distinte; $i$ solchi branchio-cardiaci appaiono poco evi-

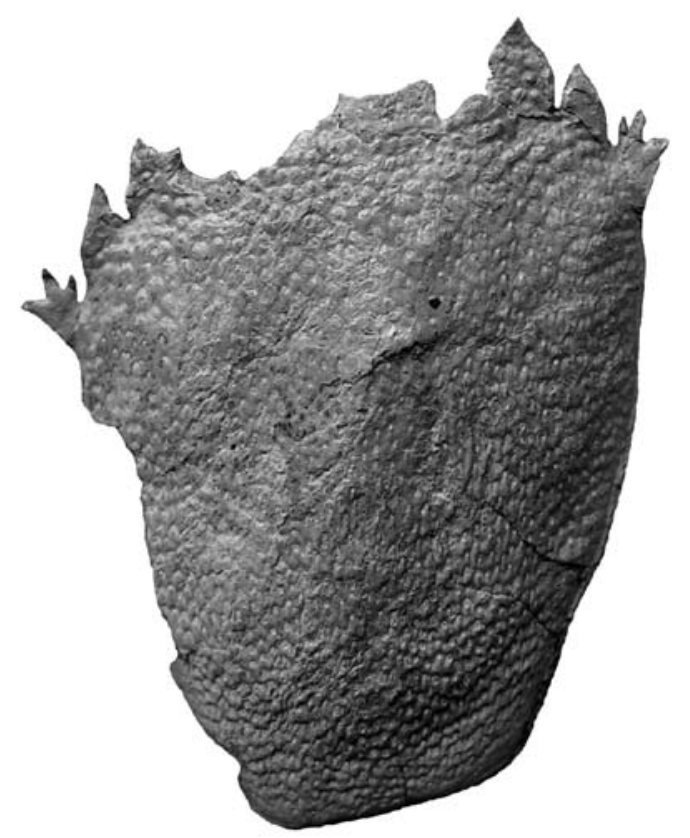

Fig. 11 - ?Ranina ornata De Angeli \& Beschin, 2011; holotype, MCZ3391-I.G.336929 (x 1.8). 
denti e paralleli; la superficie anteriore e le regioni epatiche sono ornate da tubercoli appuntiti, ben pronunciati e disposti in allineamenti trasversali leggermente sinuosi; una simile ornamentazione, però a tubercoli più minuti, é presente anche sui denti orbitali e antero-laterali; sulla parte mediana e posteriore del dorso i tubercoli hanno forma triangolare, estesi anteriormente, molto fitti e disposti in allineamenti che hanno una leggera convessità posteriore."

Literal translation: carapace shield shaped, convex transversally, longer than wide; wider anteriorly; frontorbital margin wide as the anterior dorsal part (of the carapace); only the bottom part of the rostrum is preserved; incomplete supraorbital margins; postorbital spine wide at the base, convex along the outer margin, well forward projected and pointed distally; convex anterolateral margins with two flat spines; first anterolateral spine subtriangular, with curved outer margin, pointed distally and anteriorly directed; second anterolateral spine flat, outward directed and with three acute spines distally; the first spine thin and smaller than the others two; posterolateral margins slightly curved, narrowing posteriorly and ornamented by a grained ridge; straight posterior margin convex medially, and with a carinate surface on the lateral margins; indistinct dorsal regions; branchiocardiac grooves smooth and parallel; dorsal anterior surface and hepatic regions with small pointed tubercles, protruding and ranged in transversal lines, slightly sinuous; similar ornamentation, but with smaller tubercles, is present also on the orbital and anterolateral spines; on the median and posterior dorsal part (of the carapace) the tubercles are triangular, forward protruding, close each to others and ranged in small groups slightly convex posteriorly.

Discussion. De Angeli \& Beschin (2011), described $R$. ornata, justifing the assignment to Ranina because "though the specimen lacks the frontal part, the morphological characters are typical of the genus Ranina Lamarck, 1801". Moreover, the authors justified the new species due to the "different dorsal ornamentation that, especially concerning the dorsal and posterior dorsal parts, result characteristic and almost unique for this genus" (De Angeli \& Beschin, 2011: 14 - literal translation from the original Italian text).

Based upon the review of the holotype, we disagreee with the authors' assignment, following the most recent diagnosis by Karasawa et al. (2014). Indeed, the anterolateral spines are "bifid or trifid" in Ranina (Karasawa et al., 2014: 260), whereas the first anterolateral spine is pointed, triangular and the second one trifid in $R$. ornata. Moreover the lack of the rostrum does not allow a confident assignment to the genus. The carapace is very deformed and incomplete and, though its general shape resembles that of all representatives of the Raninidae sensu stricto, the dorsal median and posterior ornamentation are quite different from Ranina, as pointed out by the authors themselves.

In conclusion we question the placement of ornata within this genus based upon the poorly preserved, deformed carapace and above all the lack of important distinctive characters, such as the rostrum, the different shape of the anterolateral spines, and the peculiar dorsal ornamentation.
?Ranina speciosa (von Münster, 1840)

Fig. 12

Hela speciosa von Münster, 1840: 24, 25, Pl. 2, figs. 1-3.

Ranina speciosa - Reuss 1859: 22. - Bittner 1875: 10, Pl. 1, figs. 5a-5d. - Noetling 1886: 33. - Ebert 1887: 266, Pl. 9, fig. 1. - Oppenheim 1903: 196. - Fabiani 1910: 91. - Glaessner 1929: 363. - De Angeli et al. 2009: 120, 121. - Beschin \& De Angeli 2001: 20. - Schweitzer et al. 2010: 74. - De Angeli \& Beschin 2011: 13, 15, Tab. 1. - Van Bakel et al. 2012: 209. - Karasawa et al. 2014: 260.

Hela speciosa - Lörenthey in Lörenthey \& Beurlen 1929: 109, 110.

Type Material: lectotype, BSPG AS VII 770.

Type locality: Osnabrück, NE Germany.

Geological age: Oligocene (Germany); late OligoceneMiocene (N Italy).

Examined material: lectotype; three additional specimens from the early Oligocene (Rupelian) of Ciglione, Amione river and Ponzone (Alessandria, Piedmont) housed in the Museum of Ovada, Piedmont, N Italy.

Description by von Münster (1840): "Der Rückenschild (Carapax) elliptisch, länger als breit, bei alten Individuen sehr flach gewölbt, in der Mitte am stärksten, gegen den Schwnnz eine schwache Einbiegung; bei jungen Individuen stärker und gleich gewölbt; an der vordern Seite befinden sich elf Zähne oder Zacken verschiedener Gröfse, in der Mitte ein gerader, eekig-zugespitzter, karzer Zahn mit zwei halhzirkelförmigen Ausschnitten an der Seite, welche zwei kurze, schief nach aufsen gerichtete Zädne begrenzen, die auf der andern Seite durch zungenförmige Ausschmitte von zwei kurzen nach Innen gekehrten Zähacn getreant sind; dann folgen, durch einen schmalen Ausschmitt getrennt, zwei lange nach eben der Richtung gebogene Zacken, welehe nach der innern Seite einen kurzen breiten Zahn haben, weiter abwärts von jeder Seite noch zwei kurze inwärts gehogene Zähne, von welchen das lette Paar schon ganz an der Seite, da wo der Schild am breitesten ist, sitzt; die Oberfläche der Schale ist fein, verschiedenartig gezahnt, nämlich die mordere Hälfte hat kurze hreite Erhöhnngen, die oben mit vier bis fünf Knötechen besetzt sind, wie die vergröfserte Abbildung Taf. II. Fig. 6. zeigt; mehr in der Mitte haben die Erhöhungen zwei bis drei dergleichen Knötchen, ode res sind solche vertiefte Pünkte in der Schnle; auf dem hintern Theil der Schale sind dreieckige kleine Zähne mit nar einem Knötchen an der Spitze, wie die vergröfserte Abbildung Fig. a. zeigt; gegen den kleinen Schwanz wird der Schild bedentend schmnder; der Schwanz hat sechs unter dem Körper gebegene Glieder, welche in der Mitte und am Rande gewölbte Erhöhungen haben, wodurch an beiden Seiten der mittlern Erhöhung flache Rinnen entstehen; die Schale des Schwanzes ist glatt mit wenigen vertieften Punkten and en Rändern der Gelenke; die Scheere des ersten dicken Fufspaares ist flach zusammen gedrückt, sehr breit, nach der innern Seite stark, wie ein Hahmenkamm, gezahnt; der änfsere Rand mit Warzen besetzt; die Finger bilden einen 
rechten Winkel mit der Axe der Scheere, der bewegliche Finger ist sichelförmig gebogen, auf dem Rücken dicht mit grofsen Warzen besetzt, und hat an der Basis nach aufsen einen langen Zaha, der eben so wie beide Scheerenfinger nach der innern Seite mit starken Knoten besetzt ist; die Schale der Scheere hat übrigens kurze und unregehnäfsige bohe Streifen, welche auf der Kante mit kleinen Knötchen, wie die Zähne auf dem Rückenschild, besetzt sind; die übrigen Fufspaare sind ebenfalls sehr dick, an den vorliegenden acht Exemplaren ist jedoch keiner dieser Füsse ganz erhalten; beim zweiten und dritten Paar, von welchen am meisten vorhanden ist, scheinen am Ende breite, flache, ruderförmige Nägel, wie beim Genus Ranina oder bei dem letzten Fufspaare des Portunus gewesen zu seyn; an allen Fufspaaren zeigen sich auf dem Schenkel und der Scheine bogenförmige erbabene Streifen mit kleinen Knötchen besetzt, die fast wie Gelenke ausschen; die Gröfse der verschiedenen Theile dieses Krebses sind aus der Zeichnung Taf. II; genau zu ersehen, wo das gröfste Exemplar meiner Sammlung abgehildet ist; jüngere Individuen sind kaum halb so grofs, haben aber alle die nämliche Gestalt und die nämlichen Verhältnisse; anfser den bei Bände gefundenen Exemplaren lesitze ich auch Bruchstücke, welche bei Bodenburg im Hildesheimischen vorgekommen sind."

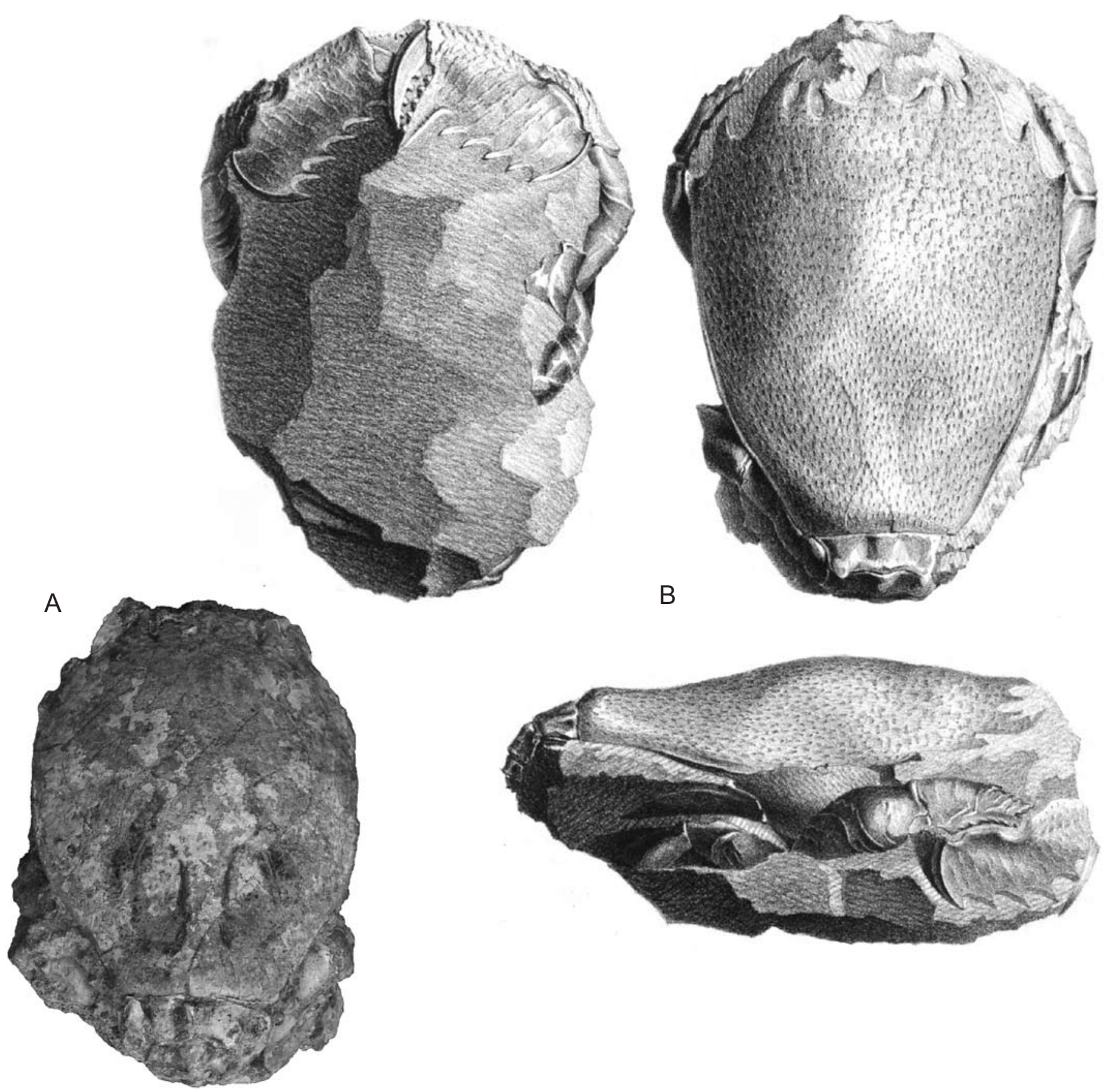

Fig. 12 - ?Ranina speciosa (von Münster, 1840). A) lectotype, BSPG AS VII 770 (x 0.6). B) von Münster’s original figures (Pl. 2 , figs. 1-3). 
Literal translation: carapace elliptic, longer than wide, in all specimens very shallowly arched, mostly in the center; towards the pleon a weak incision; in juvenile specimens stronger and regularly arched; along the frontal area there are eleven teeth or spines of different sizes, in the middle a straight, short, angular-pointed tooth with two lateral semicircular incisions, which are bordering two short, frontolaterally pointing teeth, which are separated at the other side by tongue-like incisions from two short, inwards-curved teeth; they follow, separated by a narrow incision, two long spines of the same direction which bear a short, broad tooth along their inner margin; more anterior at both margins (of the carapace) two short, inwards-curved teeth follow, of which the last pair at the lateral margin, just where the carapace has its maximum width; the surface of the shell is fine denticulate in different ways, the anterior half (of the carapace) bears short, broad elevations, which have at their upper side four to five nodules, as it is shown in the closeup of Pl. 2, fig. 6; more to the center the elevations have two or three of those nodules, or there are pits on the surface; on the posterior part of the carapace the shell exhibits triangular small denticles with only one nodule at the tip, as it is shown in the close-up of Fig. a; towards the short pleon, the carapace becomes much narrower; the pleon consists of six segments curved under the body, which have arched elevations both in the middle and at the margin, which causes shallow channels along both sides of the median elevation; the shell of the abdomen is smooth, with a few pits along the margins of the joints; the chela of the first thick pair of pereiopods is flatly compressed, very broad and at its inner margin strongly serrate, like a cockscomb; the outer margin bears pustules; the fingers form a right angle with the axis of the chela, the free finger is curved, dorsally densely postulate, and bears at its marginal base a long tooth, which bears strong nodules at the inner margin, like in both fingers the shell of the chela shows short, irregularly high striae, which are finely postulate at the edge, as in the teeth of the carapace; the other pairs of pereiopods are also very thick; in the eight studies specimens no one of these pereiopods is completely preserved; the second and third pairs, which are the most complete ones, seem to terminate in broad, flattened oar-shaped nails, like in the genus Ranina or in the last pair of Portunus; in all pairs of pereiopods both the femur and tibia bear curved elevated striae covered with small nodules which somewhat resemble joints.

Discussion. The specimen described and figured by von Münster (1840: Pl. 2, figs. 1-3) preserves the whole carapace with complete frontal margin and anterolateral spines. However the lectotype (BSPG AS VII 770) lacks the frontal and anterolateral spines (Fig. 12A), probably broken after the description by von Münster (1840). Based upon the general morphological characters of carapace, the lectotype can not be assigned to Ranina, differing in having long orbital spines inwards curved and, above all short pointed triangular anterolateral spines inward curved. In conclusion, though the above-mentioned characaters allow us to attest the assignment of this species to the Raninidae sensu stricto, the lack of the main diagnostic characters of Ranina questions the placement of speciosa within this genus.

Bittner (1875) reported an incomplete carapace from the early Miocene of Monfumo (Treviso, NE Italy), whe- reas Oppenheim (1903) reported the species from the Brocchi quarry near Bassano (Vicenza, NE Italy). We were unable to revise these specimens (probably now lost) in order to discuss their assignment.

De Angeli \& Beschin (2011: 16) discussed the assignment of some species reported by Ristori (1889) from the Miocene of Sassello (Savona, Liguria) and by Allasinaz (1987) from the late Oligocene (Rupelian) of the LigurePiemontese Basin (NW Italy), to R. speciosa. According to De Angeli \& Beschin (2011), these specimens are quite different from the type species described by von Münster (1840) in having triangular pointed rostrum, elongate, curved orbital spines, both short triangular anterolateral spines inward curved, and different dorsal ornamentation. These Italian specimens were revised by Pasini \& Garassino (2017) in order to clarify their systematic position within the Raninidae sensu stricto.

\section{RANINA NOMINA DUBIA}

Four species are included in this section, lacking generic characters useful for their assignement to Ranina. Therefore we consider these species as nomina dubia.

\section{Ranina elegans Rathbun, 1945}

Fig. 13

Ranina elegans Rathbun, 1945: 375, P1. 55, Figs F, G.

Ranina elegans - Schweitzer et al. 2010: 74. - De Angeli \& Beschin 2011: 13. - Van Bakel et al. 2012: 209. Karasawa et al. 2014: 260.

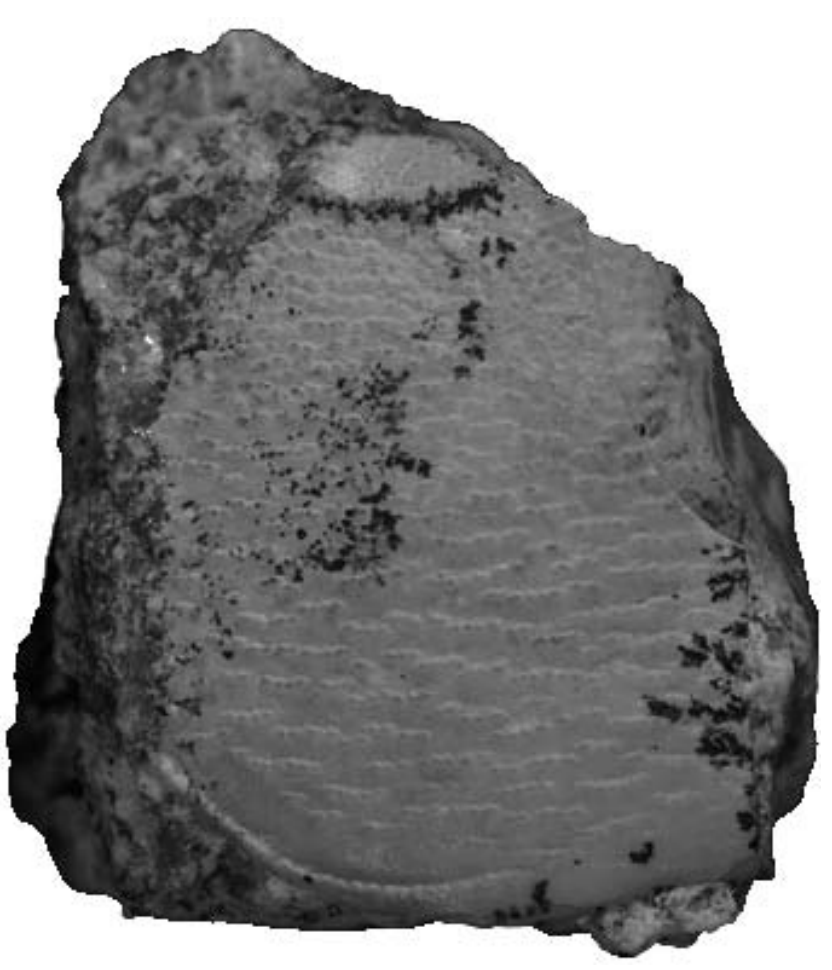

Fig. 13 - Ranina elegans Rathbun, 1945, holotype, USNM 498404 (x 5). 
Type material: holotype, USNM 498404; paratype lost (K. Hollis pers. comm., 2015).

Type locality: Vanua Mbalavu (station 110B), Lau, Fiji; Futuna formation.

Geological age: Miocene.

Examined material: holotype.

Description by Rathbun (1945): "Holotype, a portion of carapace, showing the surface of the left posterior side; surface almost level, very slightly convex; the major part is covered with short, irregular, transverse raised lines, composed of rounded granules directed forward; the anterior and anterolateral regions are more closely roughened; posterior end bluntly thickened; in front of it a long curved row of granules which trends inward a little toward a median gap; the ornamentation of the exposed surface is longitudinally oblique to the marginal line and consists of slightly arched lines edged with minute granules."

Discussion. Based upon Rathbun's description and figures, it is difficult to determine a generic placement for this specimen, lacking all Ranina characters. Moreover the paratype, consisting in a left palm and figured by Rathbun (1945: Pl. 55, Fig. G) is today lost. The inability to recognize the diagnostic characters of Ranina questions the placement of elegans within the genus.

However the presence of short transverse raised lines with rounded granules does not fit into the typical ornamentation of Ranina, remembering instead the transverse tegulate ornamentation of Lophoranina.

Ranina hirsuta Schafhäutl, 1863

Ranina hirsuta Schafhäutl, 1863: 224.

Ranina irsuta [sic] - De Angeli et al. 2009: 120.

Ranina hirsuta - Ebert 1889: 133. - Glaessner 1929: 362. - Schweitzer et al. 2010: 74. - De Angeli \& Beschin 2011: 13. - Van Bakel et al. 2012: 209. - Karasawa et al. 2014: 260.

Type material: Dr. Hell private collection, probably lost (G. Schweigert pers. comm., 2014); holotype not figured by the author.

Type locality: Kressenberg (Bavaria, southern Germany).

\section{Geological age: middle Eocene.}

Description by Schafhäutl (1863): "Eine parabolish gewölbte Gestalt von mittlerer Grösse, länglich, keulenförmig oder eigentlich ein verkehrtes, etwas in die Länge gezogenes, gleichschenkeliges Dreieck mit sphäroidischen Seiten bildend; die obere breite Seite des Schildes oder die Basis des verkehrten Dreieckes ist nicht eben, wie bei den bisher beschriebenen Formen, sondern sie bildet eine Bogenlinie oder einen Kreisabshnitt, in dessen höchstem Punkt die Stirne liegt, welche concav ausgeschnitten und an beiden Seiten mit Zähnen gekrönt gewesen zu sein scheint; die Orbital-Aus-schmitte sinken zu beiden Seiten der Stirne in dieser Bogenlinie des Oberrandes herab, machen also einen stumpfen Winkel mit der Stirne und haben sich an ihrem äussersten Ende gleichfalls in einen Zahn verlaufen; ein weiterer bogiger Einschnitt verbin- det diesen Theil mit dem Randzahne; die Oberfäche des Schildes unterscheidet sich dadurch von allen bisher beschriebenen Specien, dass ihr die schuppig über einander liegenden, gezahnten Querbäuder fehlen; dagegen ist die ganze gewölbte Fläche mit nach vorn gerichteten, keulenförmigen, un ihre sehr eigene Breite aus einander liegenden Wärzchen bedeckt, welche an den Seiten über der Leber- und Branchialgegend in nicht sehr regelmässigen Querreihen, in der Mitte des Schildes aber im Quincunx stehen; die Wärzchen sind an ihrer keulenförmigen Spitze offen, weil wahrscheinlich ihre Spitze abgebrochen ist; auch hier bildet die Stirneinfassung ein gekörntes Band, welches sich durch seine halbkugelförmigen Körnchen von dem übrigen warzigen und stacheligen Theile des Schildes vohl unterscheidet; ist nicht Ranina Aldrovandii; denn obwohl in dieser Species die Genitalfurchen fehlen, so sind hier wellige, gezähnte Bänder, die auch der Originalholzschnitt in Aldrovandi's Museum Metallicum $p .451$ angibt, und nicht bloss Reihen keulenförmiger Wärzchen vorhanden; aus dem Josephsflötze. Einziges Exemplar in Dr. Hell's Sammlung."

Literal translation: a parabolic-shaped form of medium size, elongate, clavate, or a slightly elongate upside-down orientated isosceles triangle with spheroidic margins. The upper, broad part of the shield or the basis of the upsidedown triangle is not planar like in the previously described species, but forms a bow line or a circular section, where the frontal area represents the highest point, which [the frontal area] is concave and dentate at both sides. On both sides of the frontal area the orbits are located deep along this bow line upon the upper margin, so they [the orbits] form an obtuse angle with the frontal area and end in a spine in their distalmost part. Another curved incision connects this part with the marginal spine. The surface of the shield differs from that in all previously described species in the lacking of dentate transverse ridges. In contrast, the entire arched area is covered with forward-directed clavate pustules, which are arranged in transversal rows in the hepatic and branchial areas, whereas in the center of the shield they are arranged in quincunx. These pustules have open tips, which are probably broken. The frontal margin forms a pustulate band, which well differs from the other pustulate or spiny areas of the shield by a half-shaerical shape [of the pustules]. It is not Ranina aldrovandii, because although in this species the genital grooves are missing, the latter shows wavy, dentate bands, which are shown as well in the original figure of Aldrovandi's Museum metallicum p. 451, and not only rows of clavate pustules (as in this new species). From the Josephsflöz (an iron ore horizon). A sole specimen in Dr. Hell's collection.

Discussion. Based upon Schafhäutl's original description, there is not diagnostic features that would assign this specimen to Ranina. Moreover, the lack of figures of this species makes impossible to look at the shape of the carapace and to point out diagnostic characters useful for its assignment. Just the ornamentation of the dorsal surface of the carapace with granules could fit Ranina ornamentation, but this character is not enough for its specific attribution. In conclusion, the inability to recognize the diagnostic characters of Ranina and the lack of figures question the placement of hirsuta within this genus. 
Ranina lamiensis Rathbun, 1945

Fig. 14

Ranina lamiensis Rathbun, 1945: 374, Pls. 55A, 56A, B.

Montezumella lamiensis Rathbun, 1934: 239, P1. 44, fig. 9.

Ranina lamiensis - De Angeli et al. 2009: 120. - Schweitzer et al. 2010: 74. - De Angeli \& Beschin 2011: 13. - Van Bakel et al. 2012: 209. - Karasawa et al. 2014: 260.

Type material: holotype, USNM 498402, today lost (K. Hollis pers. comm., 2015).

Type locality: Vitilevu Island (Fiji).

Geological age: Suva Formation, Neogene.

Examined material: Rathbun's plates (Pls. 55A, 56A, B).

Description by Rathbun (1945): "Carapace broadoval, nearly as broad as long, convex from side to side, less so longitudinally; width at anterior teeth less than that of middle of carapace; outer tooth long and stout and strongly curved outward; more than half way to middle a blunt-pointed triangular tooth directed forward; on the left side and farther from the middle, two adjoining teeth, tips broken off, the outer one small and spiniform, and the inner one broad, its inner margin convex; an exposed inner layer is covered with separated granules varying in size and distance; a superimposed layer shows at the rear end numerous small longitudinal granules facing forward; near the anterior lefthand corner there is a small piece of the outer layer decorated with very fine granules arranged in irregular groups."

Discussion. Based upon Rathbun's description and figures, the specimen lacks anterolateral margins, front, and anterolateral spines, making impossible any certain specific assignment. In conclusion, the inability to recognize the diagnostic characters of Ranina questions the placement of lamiensis within this genus.

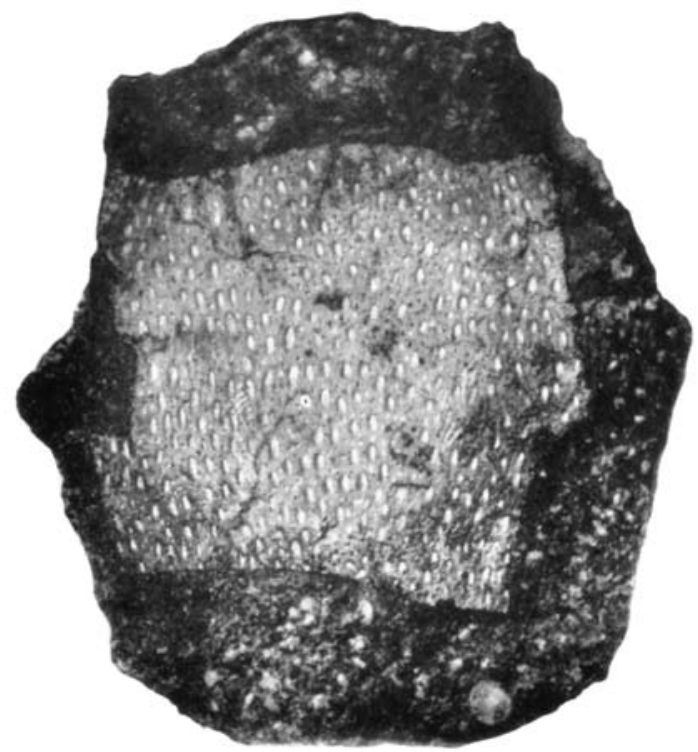

Fig. 14 - Ranina lamiensis Rathbun, 1945, holotype, USNM 498402, (Pl. 55, fig. A).
Ranina tejoniana Rathbun, 1926

Fig. 15

Ranina tejoniana Rathbun, 1926: 90, fig. 1, P1. 22, figs. 1,2 .

Ranina tejoniana - Glaessner 1929: 363. - De Angeli et al. 2009: 120. - Schweitzer et al. 2010: 74. - De Angeli \& Beschin 2011: 13. - Van Bakel et al. 2012: 209. - Karasawa et al. 2014: 260.

Hela tejoniana - Lőrenthey in Lőrenthey \& Beurlen 1929: 109.

Type material: holotype, CASG 2815.

Type locality: west side of Tecuya creek, California, USA; Tejon Formation.

Geological age: Paleogene (Eocene series).

Examined material: holotype.

Description by Rathbun (1926): "Carapace very convex from side to side, nearly flat from front to back; sides of carapace as preserved very arcuate, armed with two depressed spines the origins of which are to be seen on the left side; the posterior of the spines, at the anterolateral angle, is smaller than the other; its cross-section is a little more than twice as long as wide, the cross-section of the larger is three times as long as wide, and the distance between them is equal to the length of the smaller cross-section; the longitudinal distance of the posterior end of the base of the posterior spine from the outer orbital angle is greater than the transverse distance of that angle from the line of the greatest width of the carapace; only two orbital teeth, the two outermost, are visible; both are truncate, separated by an open suture, inclined a little inward; outer margin of outer tooth very oblique and slightly convex, a point at its outer corner has been broken off; similar spines may have been present at the corners of the second tooth; very little of the true outer surface of the carapace remains; a small piece near the anterior middle is smooth, while another piece near the lateral spines bears a few granules directed forward; underlying surfaces are granulate, the granules thinning out toward the middle; the pterygostomian regions are swollen; the merus of the left outer maxilliped is fairly complete; it is rather short and broad with a deep inner groove; the outer margin of the exognath is very convex; the episternum is subcircular, broadly pointed at the extremity and invaginated in the first sternal somite from which it is separated by a narrow fissure on each side; The first somite is characteristically broad, the lateral extremities have not been uncovered."

Discussion. Rathbun (1926: 90) described R. tejoniana by a sole incomplete carapace preserving partially some dorsal and ventral parts. Indeed, the original dorsal exocuticle is very poorly preserved, the frontoorbital margin and anterolateral spines are incomplete, and rostrum lacks. Just the sternum shape shows the general characters of Raninidae sensu stricto. In conclusion, the inability to recognize the diagnostic characters of Ranina questions the placement of tejoniana within this genus. 

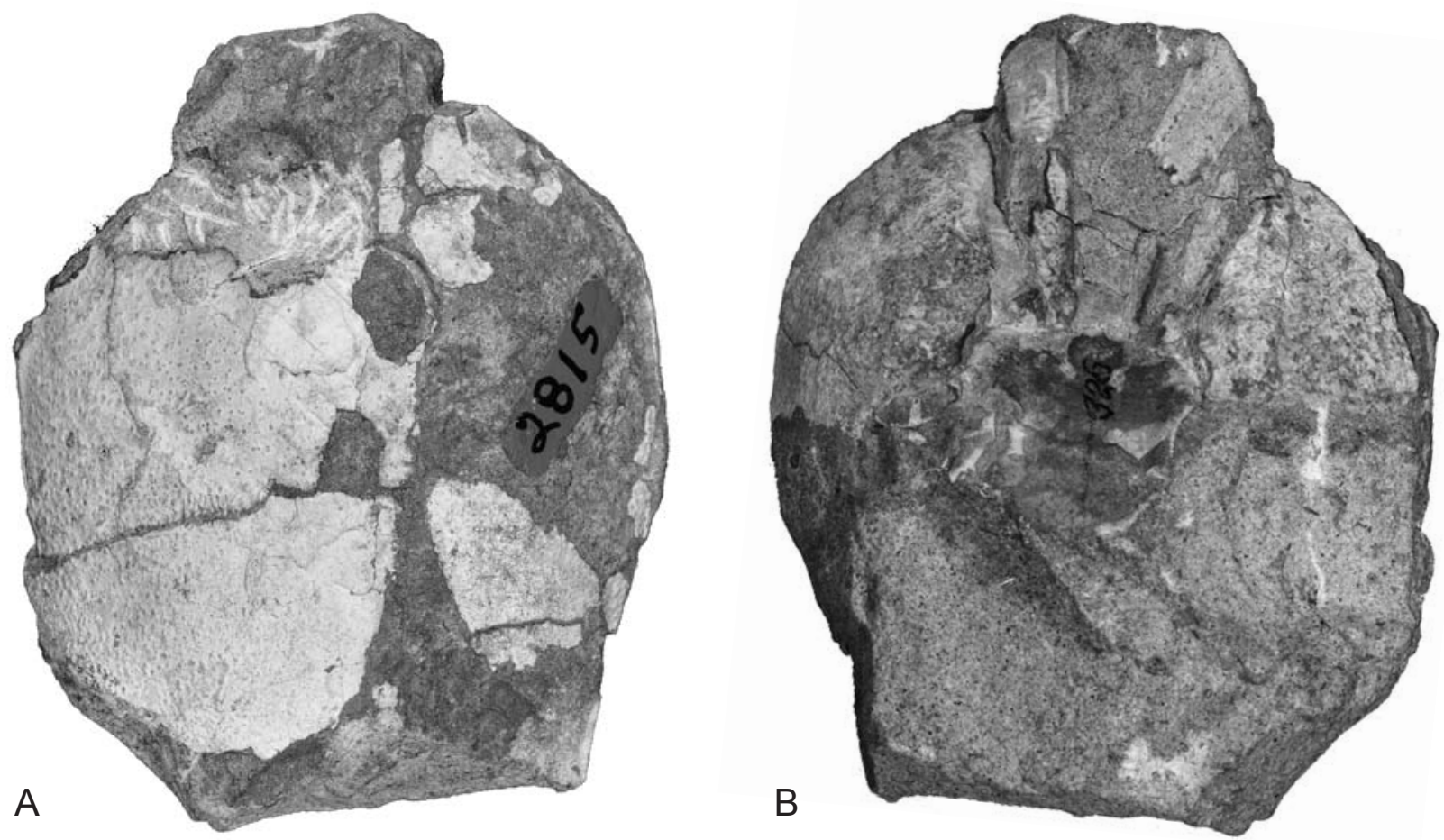

Fig. 15 - Ranina tejoniana Rathbun, 1926; holotype, CASG 2815. A) Dorsal view. B) Ventral view. (x 1.4).

\section{SPECIES ATTRIBUTED TO OTHER RANINID GENUS}

Fabiani (1910) erected Lophoranina to distinguish the species having caparace with "granulate subparallel transverse rims" from those having carapace with "granulations or small spines arranged more or less uniformly on the dorsal surface, but never arranged in subparallel transverse rims" (= true Ranina). Therefore the four species treated below for the peculiar transverse rims of the dorsal surface of the carapace are ascribed to Lophoranina.

Lophoranina bavarica (Ebert, 1887) n. comb.

Fig. 16

Ranina bavarica Ebert, 1887: 264, Pl. 8, figs. 5-9.

Lophoranina bavarica - Lőrenthey in Lörenthey \& Beurlen 1929: 105, 110.

Ranina bavarica - Van Bakel et al. 2012: 208. - Karasawa et al. 2014: 260.

Type material: lost (Bundesanstalt für Geowissenschaften und Rohstoffe).

Type locality: Kressenberg (Bavaria, southern Germany).

Geological age: Eocene.

Examined material: Ebert's original plate (Pl. 8, figs. 5-9).

Description by Ebert (1887): "Der Gruppe der R. Marestiana angehörig, ist diese aus dem Eocän des Kressenbergs stammende Art ebenfalls mit gezähnelten Querleisten auf der Oberseite des mässig gewölbten Carapax versehen, jedoch mit Ausnahme eines ziemlich breiten Bandes am Vorderrand, welches etwa dureh eine Verbindungslinie des zweiten rechten Seitendornes mit dem zweiten linken vom übrigen Theil des Rückenschildes abgeschnitten wird. Dieses Band ist nur mit unregelmässig vertheilten, nach dem Vorderrand verschwindenden Hökkerchen besetzt, welche sich öfter paarweise gesellen; der Vorderrand ist an der Stirn zu einem dreispitzigen schmalen Lappen ausgezogen, der Orbitalrand beiderseits durch zwei Einschnitte, von denen der innere noch einmal so tie fist als der äussere, in drei Theile getheilt; der innerste und grösste Theil ist tief ausgehöhlt; der mittlere zalmartig von beiden Seiten stumpf zugeschärft; der äussere anfangs eben, steigt sehr bald zu dem ersten Seitenzahn aufwärts; die Entfernung zweischen dem reehten und linken ersten Seitenzahn beträgt 24 Millimeter; der zweite und dritte Seitenzahn sind am vorliegenden Stück beiderseits abgebrochen, scheinen aber ziemlich stark und nach vorn gerichtet gewesen zu sein; die gezähnelten Querleisten laufen wellenförmig, im mittleren Theil in schwachen Zickzacklinien von einer Seite zur anderen, gabeln sich auch ab und zu, im hinteren Theil des Carapax constant; die Zähne der Querleisten sind je nach dem Erhaltungszustand spitz oder abgerundet; die Länge des Carapax, von der Spitze des Stirnlappens bis zum Hinterrand beträgt 47 Millimeter, die grösste Breite 36 Millimeter (Verbindungslinie der beiden hintersten Seitendornen); die Unterseite (Fig. 6A) des vorliegenden Exemplars, theilweise vorzüglich erhalten, lässt Folgendes erkennen; das Pterygostom wird durch ein linienförmiges, aus dicht aneinandergedrängten Körnchen gehildetes Leistechen in seiner vorderen, spitzwinkligen Fläche in zwei Theile getrennt; der innere ist glatt, der äussere 
mit linienförmigen Querrinnen versehen, die selten über die ganze Fläche sich erstrecken, sondern meist ein-oder zweimal unterbrochen sind, auch wohl alterniren; der grössere hintere Theil des Pterygostoms, den das Leistchen nicht erreicht, ist mit kleinen, bogenförmigen Rinnen bedeckt, deren convexe Seite nach hinten gerichtet und deren hinterer Rand gezähnelt ist; das Sternum zeigt die den Raninen eigenthümliche Gestalt, ist aber nach hinten stark verlängert, wobei es sich noch einmal erweitert, sodas das erste Gehfusspaar ebenfalls in eine Ausbuchtung ähnlich der des Scheerenfusses zu stehen kommt; parallel dem Rande der Scheerenfuss-Bucht läuft eine Linie kleiner Grübechen; zweischen dem Scheerenfuss und dem ersten Gehfuss, da, wo das Sternum sich lappenförmig erweitert, befindet sich ein sternaler, blattförmiger Fortsatz, der be idem vorliegenden Exemplar abgebrochen ist, und zwar so, dass seine rudimentäre Basis worhl irrthümlich als Ansatzstelle eines Fusses aufgefasst werden kann, wie es thalsächlich Brocchi ergangen ist bei Ausfstellung seiner Gattung Palaeonotopus (a. a. O.); bei der lebenden R. dentata ist dieser sternale Fortsatz ebenfalls sehr kräftig entwickelt, und ein Vergleich unseres Stückes mit drei Exemplaren der dentata ergab, dass eine anderweitige Erklärung dieses ellyptisch-cylindrischen, dünnschaligen Organ-Rudiments ausgeschlossen ist; uebrigens ist das Basalglied der Füsse bedeutend dickschaliger und fast kreisrund; von dem Scheerenfuss sind ausser dem Basalglied noch die drei vordersten Glieder erhlten (Fig. 7), der Oberarn ist dreiseitig, die untere Seite glatt, die obere anscheinend auch, die äussere mit dachziegelartig übereinander liegenden Kammleisten besetzt; das Schienbein ist vierseitig, jedoch bezüglich der Sculptur schlecht erhalten; die Hand ist mit meist kurzen, öfter alternirenden Querleistchen verziert, ausser dem festen, rechtwinklig zur Axe stehenden Index an dem inneren Rande noch mit 4 Zacken versehen; der Daumen ist etwas gekümmt
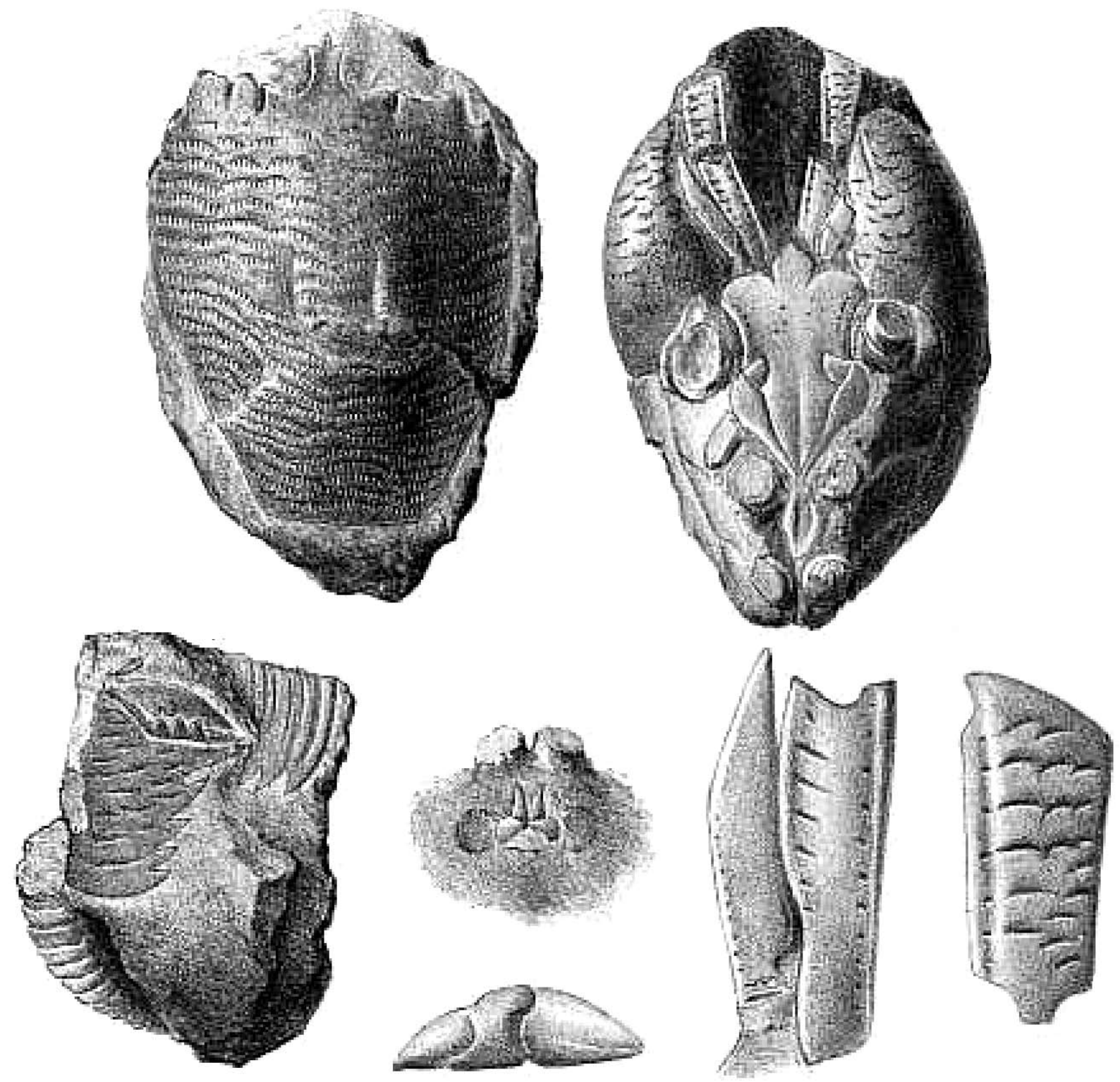

Fig. 16 - Lophoranina bavarica (Ebert, 1887) n. comb.; Ebert's original figures (P1. 8, figs. 5-9). 
und trägt hinten einen schwach gezähnelten, dornartigen Fortsatz; daumen und Index sind mit kleinen Zähnchen bewaffnet."

Literal translation: belonging to the group of $R$. marestiana, this species, which comes from the Eocene of Kressenberg, the moderately arched carapace also bears transversal dentate bands on its surface, except of a relatively broad band along the frontal margin, which is approximately delimited by a line connecting the second right marginal tooth with the opposite one; this band only bears irregularly spaced pustules, which are fading out towards the frontal margin and which are often grouped in pairs; at the front, the frontal margin is prolonged into a narrow tridentate lappet; the orbital margins are subdivided by two incisions into three sectors; the inner incision is twice as deep as the outer one; the innermost sector is deeply curved, the middle one is bluntly pointed (?) with teeth from both sides, and the outer one is straight and then rapidly grades upwards into the first marginal spine; the distance between the first right and left marginal spine is $24 \mathrm{~mm}$; in the present specimen the second and third marginal spines are broken off at both margins, however, it seems that they had been rather strong and forwardly directed; the dentate transverse bands are wavy, in the central part in weak zigzag lines, sometimes they are bifurcating, in the posterior part of the carapace constantly; the teeth of the transversal bands are pointed or rounded, due to their preservation; the length of the carapace, measured from the tip of the rostrum to the posterior end, is $47 \mathrm{~mm}$; the maximum width is $36 \mathrm{~mm}$ (between the posteriormost marginal spines); the ventral part of this specimen (fig. 6), which is in part perfectly preserved, shows the following features; the pterygostome is subdivided in its anterior area by a linear crest, which is formed by densely arranged grains (pustules) into two sectors; the inner one is smooth, the outer one ornamented with linear transversal grooves, which are often interrupted or which alternate; the larger posterior part of the pterygostome, which is not reached by the crest, is covered with small curved grooves, the convex side of which points to the posterior side, and their posterior margins are denticulate; the sternum shows the typical shape of raninids, but is strongly elongate posteriorly and wide, so that the first pair of walking legs is located in an indentation similar to that of the chelate leg; parallel to the indentation of the chelate leg there is a line of small pits; between the chelate leg and the first walking leg, where the lappeted sternum widens, there is a leaflike extension, which is broken off in the studied specimen and which may be erroneously taken as the basis of another pereiopod; this happened to Brocchi when he erected his genus Palaeonotopus; in the extant $R$. dentata this sternal extrusion is developed very strong as well, and the comparison with three specimens of $R$. dentata clearly showed that another explanation for this ellipticcylindrical, thin-shelled rudimentary structure can be excluded. By the way, the basal article of the pereiopods are much thicker-shelled and almost rounded; besides the basal article also the three distal articles of the cheliped are preserved (fig. 7); the carpus is three-sided (? triangular); its lower side is smooth, obviously the upper side is smooth, too, whereas the marginal side is covered with comb-like crests; the merus is four-sided (?square), its ornamentation, however, is poorly preserved; the propodus is ornamented with alternating short transverse crests and bears a fixed finger perpendicular to the longitudinal axis (of the propodus) and four pinks along the inner margin; the dactylus is slightly curved and bears proximally a weakly dentate spine-like protrusion; dactylus and index both have small teeth.

Discussion. The specimen, as described and figured by Ebert (1887: 264, Pl. 8, figs. 5-9.), shows the typical dorsal ornamentation of the carapace of the representatives of Lophoranina, having finely granulate subparallel transverse tegulate rims. In conclusion, based upon the dorsal ornamentation of carapace we can assign bavarica to Lophoranina.

Lophoranina fabri (Schafhäutl, 1863) n. comb.

Fig. 17

Ranina fabri Schafhäutl, 1863: 222, 223, P1. 60, fig 1a, b; Pl. 61, fig. 1.

Lophoranina fabri - Lőrenthey in Lőrenthey \& Beurlen 1929: 110.

Type material: lectotype, BSPG 1873 III G 65, herein designated.

Type locality: Kressenberg (Bavaria), Germany.

Geological age: middle Eocene.

Examined material: lectotype and BSPG 1873 III G 511 (figured in Pl. 61, fig. 1).

Description by Schafhäutl (1863): "Eine verhältnissmässig nicht sehr grosse, längliche Gestalt vom Umrisse eines verkehrten Eies, dessen oberer und unterer gewölbter Theil quer abgeschnitten ist; der Cephalothorax, welchrer allein erhaiten ist, verschmälert sich nach dem Leibe zu nur sehr wenig und allmählich; er ist stark und etwas parabolisch gewölbt der Längenaxe und dicht bedeckt mit queren, welligen, schmalen Bändern, welche dachziegelförmig über einander üegen, mit ihrem freien Rande gogen die Stirn gerichtet; jeder dleser freien Rãnder ist kammartig, dicht gezähnelt, die Zähnchen erscheinen unter der Lupe als hohle Röhrchen mit etwas zusammengezogener Mundöffnung litt. b; diese Bänder laufen nicht immer regelmässig über den ganzen Leib; schon das dritte oberste endet an beiden Seiten in der Lebergegend; in der Mitte des Rückenschildes werden sie von zwei, etwas nach unten zu convergirenden Längsfurchen unterbrochen, welche die Genitalgegend bezeichnen litt. a; sie setzen über diese Genitalgegend wieder fort, krümmen sich im mittleren und unteren Theile abwärts, im obern immer mehr und zwar pyramidenartig aufwärts; die oberste Binde erhebt sich zu einem gleichschenkeligen Dreieck, dessen Scheitel in eine aus Körnern in abnehmender Grösse zusammengersetzten Spitze endet, welche die Axe des Schildes bezeichnet und unter der Stirne endet; die oberste Einfassung des Schildes, welche die Stirne und die Augenhöhlenpartien umfasst, ist ohne Bänder, aber ziemlich dicht mit Warzen bedeckt; diese Einfassung ist durch flache Längsfurchen an jeder Seite der mittle- 
ren gekörnten Genitalien-Spitze in zwei etwas cylindrisch gewölbte Theile getheilt, unter welche die Fühler und Augen zu liegen kommen; schon durch diese nur vierfache Theilung des Stirnbandes unterscheidet sich unsere Species von dem übrigen; der Räckenschild schlägt sich unter einer scharfen Kante nach der untern Kopfseite des Schildes über Taf. LXI. Fig. 1, ist hier, nur einen schmalen, vorkehrt- und lang-dreieckigen, eingesäumten Rand von 6 Millimeter grösster Breite bildend, ebenso zahnig geschuppt, nur schwellen hier die Zähne zu Warzen auf, so dass auf dieser schmalen Leiste die schuppige Structur mehr und mehr verschwindet; dagegen sind die, nahezu ein rechtwinkeliges Dreieck bildenden Segmente, weiche die etwas verkehrt-eiförmige Buccalöffnung zweischen sich tragen, in derselben Weise, nur etwas weiter geschuppt und noch stärker gewölbt als der Röckeinschild selbst; unter der Buccalöffnung bemerkt man, wie auf Taf. LXI. Fig. 1, noch den ersten, obersten Theil des Sternums; alles Uebrige ist verloren gegangen; die Schale ist glänzend schwarzbraun; das gezeichncte Exemplar ist das glänzend schwarzbraune aus dem Maximiliansflötze; das zweite Exemplar ist gelblich-weiss; aus dem gelblichen Sandsteine, welcher die Sohle des Ferdinandflötzes bildet; die zwei einzigen Exemplare in Dr. Hell's Sammlung."
Literal translation: it has a relatively not very big elongate shape resembling an egg standing on its tip (author means: obovate), which is transversally cut in its upper and lower arched parts; the cephalothorax, which is only preserved, becomes smaller towards the body very gradually; it is strongly and somewhat forming an arched parabolic curve on its longitudinal axis and densely covered with transverse, wavy and thin bands, which are arranged like tiles, their free margins pointing frontally; each of these margins is densely serrate; observed with a lens, each denticle appears as a hollow tube with a narrower open ending; the bands are not arranged regularly on the entire body; already the third one ends on both sides in the hepatic area; in the middle of the carapace they are interrupted by two posteriorly converging longitudinal grooves, which mark the genital area; they (the bands) continue across this genital area, bend downwards in the middle and posterior part, but more anteriorly in the upper part, in the shape of a pyramid; the uppermost (most anterior) band forms an isosceles triangle, the pointed tip of which, bearing pustules of decreasing size and forming the axis of the carapace, finally ends at the front; the uppermost (anteriormost) margin of the carapace, which bears the front and the orbital areas, is lacking bands, but

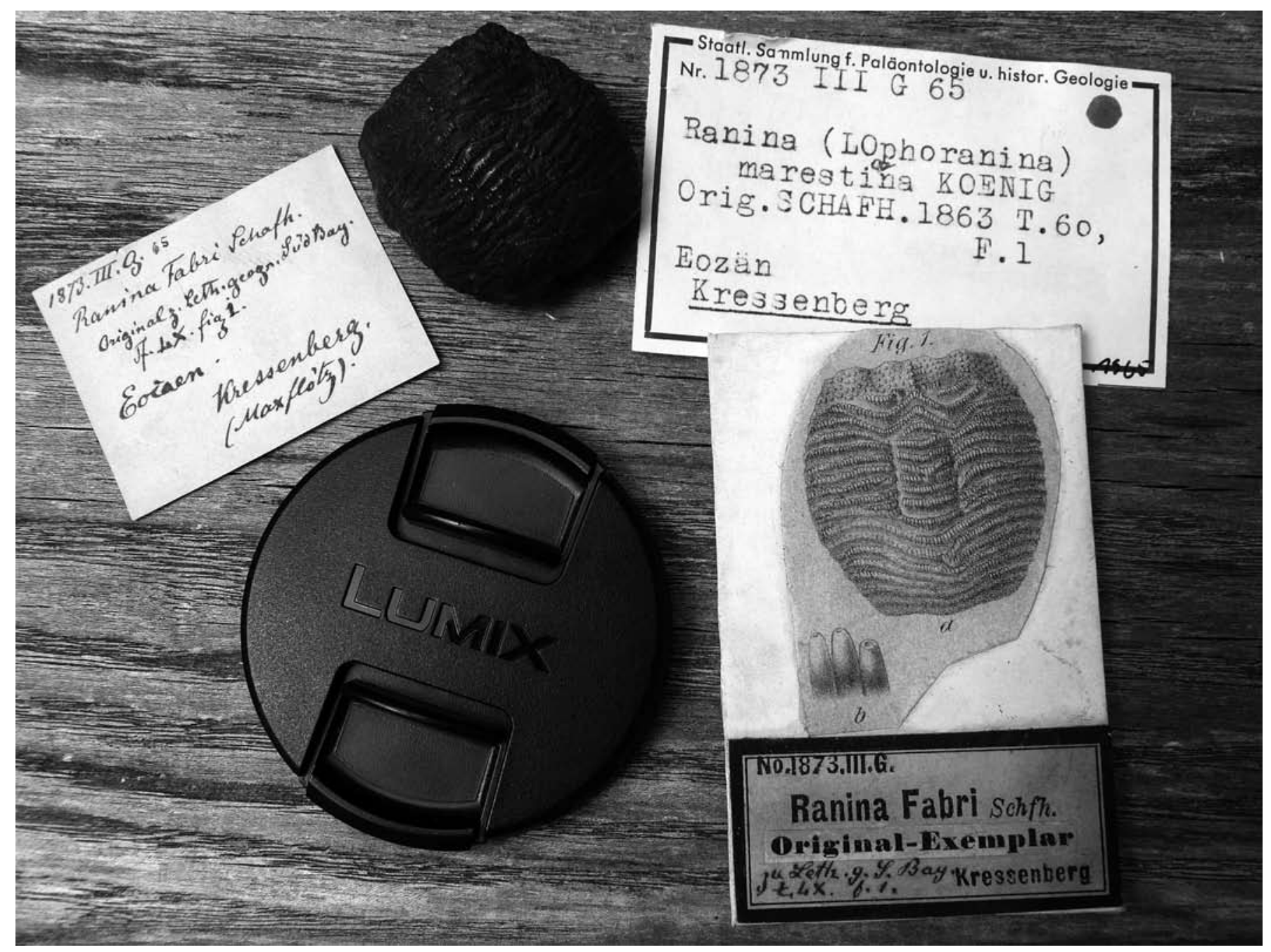

Fig. 17 - Lophoranina fabri (Schafhäutl, 1863) n. comb.; lectotype, BSPG 1873 III G 65 (x 1.2). 
densely covered with pustules; this margin is subdivided at each side of the middle genital tips by shallow longitudinal furrows into two cylindrically arched parts, where the antennae and eyes are located; even this separation of the frontal margin into only four sections is a feature distinguishing this species from other taxa; the carapace exhibits a sharp frontal edge (Pl. 61, fig. 1) and has a narrow, long-triangular band with a maximum width of 6 $\mathrm{mm}$, which bears scale-like denticles, but in this region the scales more and more disappear and are replaced by pustules; however, the almost right triangular segments enclosing the obovate buccal opening still have these scales but wider spaced and (these regions are) stronger arched than the carapace itself; ventrally from the buccal opening the anteriormost part of the sternum is discernible (Pl. 61, fig. 1); all other parts have been lost; the surface of the shell is of glittering black-brown color; the specimen of the drawing is the glittering black-brown one from the Maximiliansflöz; the second specimen is of yellowish-white color; it comes from the yellow sandstone at the base of the Ferdinandflöz; the only two specimens are in the Dr. Hell's collection (note: these two specimens are syntypes, no holotype designated here).

Discussion. Based upon Schafhäutl's description and figures, the dorsal ornamentation of the carapace clearly has transverse tegulate rims, typical distinctive character of Lophoranina to which fabri is assigned, as already considered by Lörenthey in Lörenthey \& Beurlen (1929: 110) and by Glaessner (1929: 361), without any discussion to justify this assignment. Finally, since Schafhäutl's specimens are syntypes, we designated the sole available specimen BSPG 1873 III G 65 as lectotype.

Lophoranina helii (Schafhäutl, 1863) n. comb.

Fig. 18

Ranina helii Schafhäutl, 1863: 223, 224, Pl. 60, fig. 3.

Type material: holotype, BSPG 1873 III G 363.

Type locality: Kressenberg (Bavaria), Germany.

Geological age: middle Eocene.

Examined material: holotype.

Description by Schafhäutl (1863): "Der Schild dieses ziemlich grossen Exemplars, das grösste aus dem Josephsflötze, das ich kenne, ist 64 Mimmimeter lang; es ist keulenförmig oder bidet vielmehr im Umrisse einen Rhombus mito ben stark, unten weniger stark horizontal abgeschnittener Spitze und abgerundeten Seitenecken; denn namentlich die unteren Seitenlinien bilden eine nahezu gerade Rückenschild von quer über den Schild laufenden, welligen, an ihrem Oberrande tief und dicht gezähnelten Bändern bedeckt, welche jedoch nur unter der Genitalregion, sich in einer raschen Bucht abwärts biegend, grösstentheils ohne Unterbrechung quer über die Schale laufen; diese Bänder bilden in ihrem Verlaufe, wie schon augedeutet, eine ununterbrochene Linie; sie gabeln sich manchmal im letzten Vierttheil gegen den Rand zu und erscheinen danna $m$ Rande doppelt; manchmal spalten sie sich in der Mitte auf eine kurze Strecke, manchmal nahe dem Rande, den sie aber wieder ungespalten erreichen; manchmal erscheinen sie wie aus über einander gefalzten Leisten zusammengesetzt; die Zähne greifen tief, oft bis zur Hälfte des Bandes herab, sind cylindrisch, oben abgerundet, mit einer runden Oeffnung verschen, die vielleicht von einer abgebrochenen Spitze herrührt litt. b, und dicht wie Pfähle an einander liegend; am Anfange der obern Hälfte des Rückenschildes, dem eigentlichen Cephalothorax, werden sie, sich abwärts beugend, von zwei etwas concav auswärts sich krümmenden Lvngsfurchen unterbrochen, welche die Genitalregion anzeigen und unter der Stirne, am Anfange des letzten Dritttheiles der Höhe verschwinden; von nun an zieht das erste Band wieder in gewöhnlicher Weise über den Rükken, sich in einer raschen starken Bucht auf der Axe des Schildes über den Genitalfurchen abwärts krümmend, und so setzt es ununterbrochen über 3/4 der Breite fort; in die mittlere Bucht dieses ersten Bandes senkt siche in Fragment eines darüber liegenden Bandes gleichfalls in einer abwärts gerichteten, aber schwächeren Bucht, welches aber erst im mittleren Dritttheile der Breite des Schildes entspringt; die übrigen Querbänder, welche den übrigen Theil des Schildes gegen die Stirne zu ausfüllen, nehmen von der Genitalfurche keine Notiz mehr, während bei der zuerst beschriebenen Species Ranina fabri die Genitalfurchen der Stirne viel näher liegen, die darüber liegenden Bvnder sich zu einem Dreieck über diesel Furchen in die Höhe biegen, und nnoch überdiess der Scheitel des letzten höchsten Dreiecks sich in eine gekrümmte Spitze verläuft, welche die gekörnte Stirneinfassung in zwei Hvlften theilt; and en beiden obersten Seiten des Schildes, welchen das lette Querband abschliesst, verläuft sich die Ecke in einen gerade aufwärts steigenden, mit der Spitze nach innen gekrümmten Zahn; nun beginnt gleichsam als Einfassung dieses oberen Theiles das gekörnte Band, dessen beide Seiten sich wahrscheinlich zu einer gleichen, aber stärkeren Zahnspitze erhoben; auf diese zwei starken Seitenzähne folgt nun, durch einen tiefen Einschnitt getrennt, ein halb cylindrisches, oder besser kurz keulenförmiges Stück, unter welchem vielleicht die Augenstiele sassen; das über der Stirne stehende Fragment scheint in der That der Ueberrest eines solchen Augenstieles zu sein; denn das scheinbar gabelförmige Ende scheint nur durch den Bruch des gerundeten, keulenförmigen Endes entstanden zu sein; auf diesel Theil folgt nun, innen gleich falls durch einen noch tiferen Einschnitt getrennt, der eigentliche Stirnrand; er ist durch eine flache Längsfurche, welche in die Axe des Schildes fällt, in zwei schwach gewölbte Hvlften getheilt, welche übrigens Anlage zu noch weiterer ähulicher doppelter Theilung zeigen; die Hand selbst ist unter lii. c gezeichnet; ihre Schale bestht gleichfalls aus den schuppenartig über einander liegenden, gezahnten Querbändern, welche sich an der untern linken Seite flügelartig ausbreiten; oben erweitert sich die Hand nach der Rechten in den querliegenden, ebenfalls geschuppten, horizontalen, immer mit vier stumpfen Zähnchen versehenen Finger, auf welchen der hier verloren gegangene, gleichfalls horizontale, bewegliche Daumen passte; die Handwurzel ist gewölbt, elliptisch, fässchenartig, aus acht stumpf gezähnten Schuppen oder Querbändern bestehend, bei der gezeichneten Hand 17 Millimeter lang und von 12 Millimeter grösster Breite; die Unterseite und ein Theil des Plastrons ist in Taf. LXI. Fig. 1. dargestellt, eine Figur, welche nicht Ranina Fabri, son- 
dern eine jugendliche Form von Ranina Helli ist; ist nicht Ranina Aldrovandii Dsm., wie er sie auf Taf. 10. Fig. 5. seiner Histoire naturelle des Crustacés fossiles abgebildet hat; die tiefen Längsfurchen, welche in unserm Exemplare die Genitalregion auf der Mitte des Schildes abgrenzen, fehlen hier gänzlich; dass sie der Zeichner nicht vergessen haben konnte, diess beweisen die Querbänder, welche über den Schild ziehen; sie sind durch kein Hinderniss unterbrochen; ja manches verliert sich allmählich ganz sanft in der Mitte des Rückens; auch ist die Zähnelung des Rande san seinen Querbändern viel carter und viel wenniger tief als die unserer Species; dazu kommt noch, dass in der Fig. 5. und der Profil-Figur 7. Desmarest's die Bänder anstatt an ihrem obern, an ihrem untern Rande etwas gezahnt angegeben sind und auch dachziegelförmig nach unten, anstatt wie bei unsero Exemplar nach oben, über einander liegen; im grünen, Thoneisenstein haltigen Sandsteine, welcher als Unterlage des Fernandsflötzes dient; auch im Ferdinands-, Emmanuel- und Josephsflötze; Dr. Hell's Sammlung."

Literal translation: the carapace of this relatively large specimen, the biggest one which I know from the Josephsflöz, is $64 \mathrm{~mm}$ long; it is clavate, or more exactly spoken, in the shape of a rhomb, with horizontally cut endings, especially the anterior one, and rounded marginal edges; the posterior lateral margins are almost straight; the strongly parabolically arched carapace, which is lined by a delicate hem of pustules, bears on its surface wavy bands bearing which are at their anterior parts deep and densely dentate; they only in the area posterior to the genital region form a shallow posterior bulge and run almost without interruption transversally on the carapace; the bands, as mentioned, form an uninterrupted line; sometimes they diverge in the last fourth towards the lateral margins, where they appear as double line; sometimes they diverge in the center for a short distance or sometimes close to the margin, but they reunify before reaching the margin; sometimes they appear like pleated strips; the denticles are deep [long], almost reaching the half of the band, they are cylindrical, distally rounded, with a round opening, which may result from a broken tip and densely arranged; at the beginning of the anterior half of the carapace, the cephalothorax in the strict sense, they (the here posteriorly bent bands) are interrupted by two concave longitudinal furrows bent towards the margins which mark the genital area, and they disappear in the last anterior third of the carapace; from this position onwards the first band runs in the common way on the dorsal shell, forming a deep bulge in the axis of the carapace anterior to the genital furrows and continues over a distance

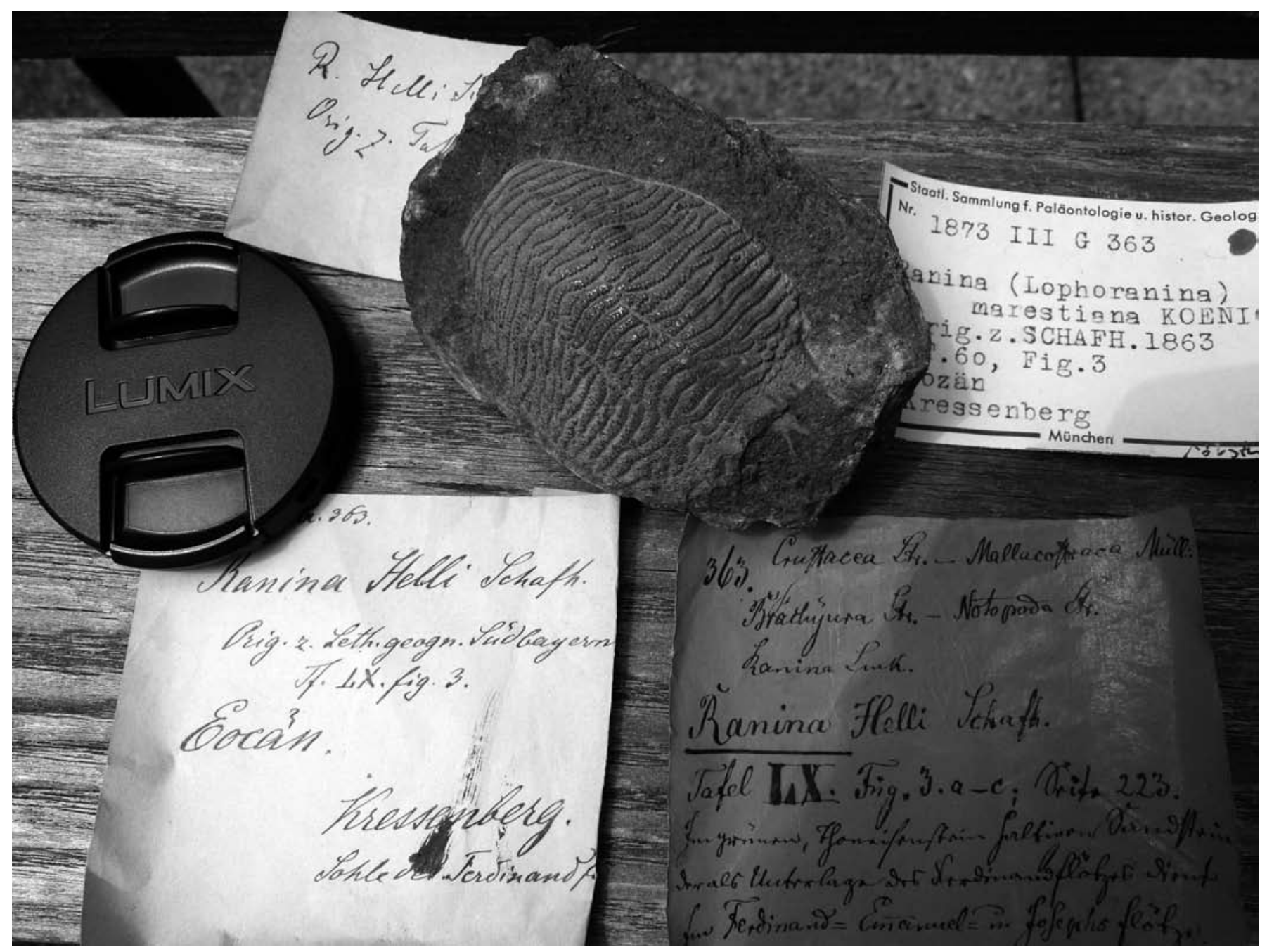

Fig. 18 - Lophoranina helii (Schafhäutl, 1863) n. comb.; holotype, BSPG 1873 III G 363 (x 0.7). 
of $3 / 4$ of the width of the carapace; in the middle bulge of this fist band sinks the fragment of the next band, forming a weaker bulge, however, it (that band) starts running in the middle third (?) of the width of the carapace; the other bands filling the space towards the front are not affected by the genital furrow, whereas in the previously described species Ranina fabrii the genital furrows are located much closer to the front, the bands anterior to the genital furrows forming triangles, and the last and highest triangle ends in a bent tip that subdivides the grained frontal area; in the position where the anteriormost transversal band reaches the margin there is a straight, forward directed tooth, the tip of which points inwards; here starts the grained band forming the hem of this area, and probably at both sides (of this band) a similar, but stronger tooth was developed; separated by a deep incision, these two strong marginal teeth are followed by a half-cylindrical, or better short clavate section, where probably the eye stalks were located ventrally; the fragment anterior to the front seems to be the rest of such an eye-stalk, because its forked (distal) end was probably just formed by crushing of the rounded, clavate end; then follows inwards, separated by a still deeper incision, the true frontal margin; the latter is subdivided by a shallow longitudinal furrow in the axis into two halves, which seem to show another subdivision of the same style; the pereiopod is illustrated in fig. 3c; its shell is also ornamented with scale-like dentate transversal bands, which are widening wing-like in their lower (proximal) left side; anterior the propodus widens towards the right side into the transversally arranged straight, scale-bearing fixed finger with four blunt teeth, which had corresponded with the straight, but now lost movable finger; the base of the propodus is arched, elliptic, keg-like and consists of eight blunt dentate scales or transverse bands; the illustrated specimen is $17 \mathrm{~mm}$ long with a maximum width of $12 \mathrm{~mm}$; the ventral side and a part of the plastron are illustrated in Pl. 61, fig. 1; this figure does not show Ranina fabri but a juvenile specimen of Ranina helli; it is not Ranina aldrovandii Dsm. as figured on Pl. 10, fig. 5 of his Histoire naturelle des Crustacées fossiles; the deep longitudinal grooves, which delimit the genital area in the center of the carapace of our specimen are missing there completely; the possibility that they were forgotten to show by the drawer can be excluded by the transversal bands running on the carapace; they are not interrupted; indeed something (of the sculpture) becomes gradually weaker in the dorsal middle; moreover, the dentition of the margins of the transversal bands are much more delicate and less deep than in our species; moreover, in fig. 5 and in the profile of fig. 7 of Desmarest the bands are illustrated as being dentate in their posterior part instead in the anterior part and are arranged like tiles towards the posterior end instead anteriorly (towards the front); in the green, siderite-bearing sandstone below the base of the Ferdinandflöz; also occurring in the Ferdinand-, Emmanuel, and Josephsflöz; in Dr. Hell's collection.

Discussion. Based upon Schafhäutl's description and figures, the dorsal ornamentation of the carapace clearly has transverse tegulate rims, typical distinctive character of Lophoranina to which helii is assigned, as already considered by Glaessner (1929: 361), but without any discussion to justify this assignment.

\section{SPECIES ATTRIBUTED TO OTHER CRUSTACEAN FAMILIES}

Calappa cuspidata (Guppy, 1909) n. comb.

Fig. 19

Ranina cuspidata Guppy, 1909: 6, fig. 1 (illustrated with anterior down).

Ranina cuspidata - Guppy 1911: 14. - Rathbun 1919: 168. - Glaessner 1929: 361. - De Angeli et al. 2009: 120. - Collins et al. 2009: 75. - Schweitzer et al. 2010: 74. - De Angeli \& Beschin 2011: 13. - Van Bakel et al. 2012: 209. - Karasawa et al. 2014: 260.

Type material: holotype and repository unknown.

Type locality: Machipur near Montserrat, Tamana district, Trinidad Island (Antilles, Atlantic Ocean).

Geological age: early Miocene.

Examined material: Guppy's original figure.

Description by Guppy (1909): "The carapace is rather evenly convex and the general contour is almost circular, anterolateral angles being formed by four flattened acute spines pointing outwards beyond the general outline of the carapace; these spinose projections are somewhat similar to the foliaceous expansions of $\mathrm{R}$. palmaea from which they differ in pointing outwards instead of forwards; the median portion of the carapace is formed by a round carina which is separated off by moderately deep grooves from the lateral portions, thus dividing the back into three parts, the median part bearing a single row of distant, low, but acuminate tubercles; and each lateral portion two rows of similar tubercles somewhat irregularly arranged."

Discussion. Based upon Guppy's description and figure, it is difficult to determine a generic placement for this specimen, lacking all diagnostic characters of Ranina. Therefore, the inability to recognize the diagnostic characters of Ranina questions the placement of cuspidata within this genus.

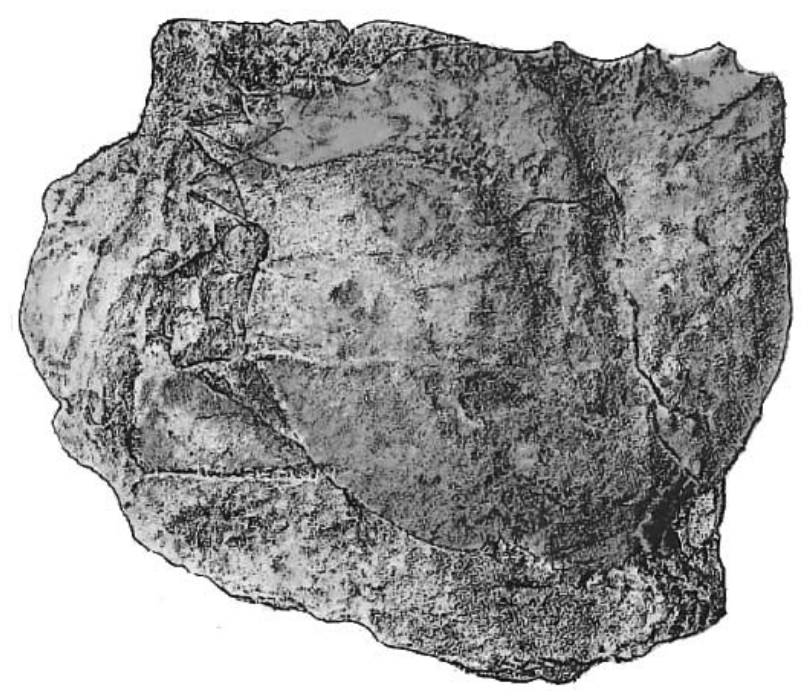

Fig. 19 - Calappa cuspidata (Guppy, 1909) n. comb.; Guppy’s original figure (Fig. 1). 
However based upon Guppy's original description and figure, the subcircular outline of the carapace larger posteriorly, the presence of a raised median carina, and the presence of strong spines along the posterior margin fit better some characters of some representatives of the Calappidae.

Though the scarce state of preservation, the sole specimen is tentatively assigned to Calappa Weber, 1795.

\section{DOUBTFUL SPECIES OF DECAPODA}

"Ranina" burleighensis Holland in Holland \& Cvancara, 1958

Fig. 20

Ranina? burleighensis Holland in Holland \& Cvancara, 1958: 504, 505, fig. 3c, Pl. 74, fig. 15.

Ranina burleighensis - Schweitzer et al. 2010: 74. - De Angeli \& Beschin 2011: 13. - Karasawa et al. 2014: 260.

Type material: holotype, USNM 562094.

Type locality: South of Moffit, Burleigh County, North Dakota, USA.

Geological age: Cannonball Formation, Paleocene.

Examined material: holotype.

Description by Holland \& Cvancara (1958): "The holotype consists of the broken distal portion (twothirds?) of the left manus, the stub of the pollex or immovable finger, and the proximal part of the dactylus of a rather large propodus; the ma us, though laterally crushed, appears to have been oblong in cross-section with the width about three-fourths the height; the outer surface of the manus is covered with irregular spaced, asymmetrical tubercles which are inclined forward; between the tubercles are smaller, more symmetrical, rounded granules; inner surface similar but with the tubercles less pronounced; the tubercles apparently disappear toward the upper surface and on the pollex; on upper distal corners of the manus near the articulation of the dactylus is

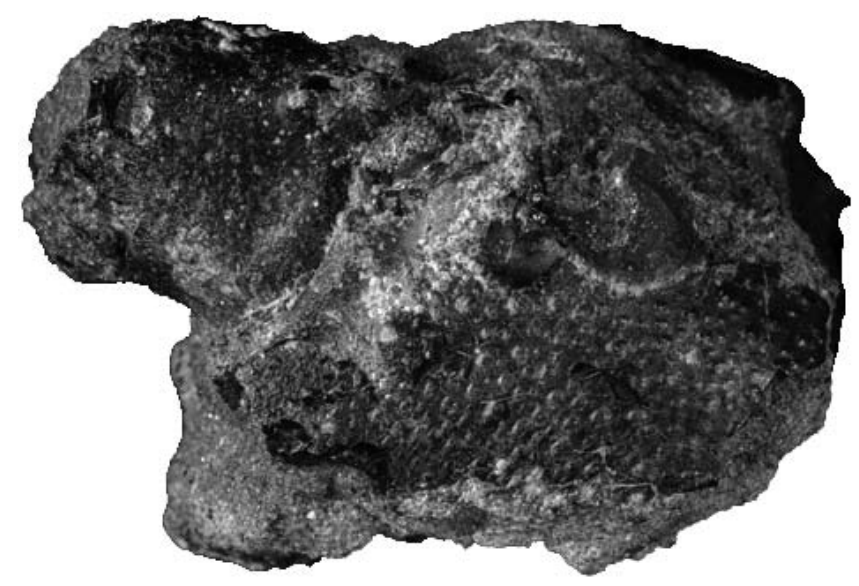

Fig. 20 - Ranina burleighensis Holland in Holland \& Cvancara, 1958; holotype, USNM 562094 (x 2.2). situated a pair of spine bases; the base of a single, small, forward-directed spine can still be seen on the outer surface near the junction with the pollex; the dactylus is so broken that it is impossible to determine its length; on the inferior surface a rounded projection appears near the break, $6.5 \mathrm{~mm}$ anterior to the junction with the manus; this projection is presumed to be the first prehensile tooth; at this place the dactylus is subovate but it expan$d s$ rapidly in a proximal direction and becomes flatter on the superior surface; posteriorly directed projections occur on the upper proximal corners of the dactylus; the projections apparently articulated with poorly preserved sockets in the upper distal corners of the manus; a spine base of an anteriorly directed spine is borne on the distal edge of each projection (the inner spine was observed by the writer but broke during preparation); the dactylus is covered with irregularly spaced shallow pits; although little remains of the pollex, it appears almost rectangular in cross-section, pitted like the dactylus, and inclined downward from the manus."

Discussion. Based upon the above-reported original description, this manus has strong propodus and dactylus that do not fit clearly the typical characters of a raninid manus. Indeed according to Feldmann (pers. comm., 2015) the manus clearly resembles that of a lobster or a xanthid. In conclusion, this species cannot be assigned to Ranina and this manus might well belong to a variety of other decapod groups.

\section{CONCLUSIONS}

As result of this first review of the fossil species of Ranina, the most recent list proposed by Karasawa et al. (2014) of 23 valid fossil species is reduced to four possible valid species, Ranina palmea, $R$. pellattieroi, $R$. propinqua, and $R$. ranina. The close revision of the type species of the extant Ranina by Luque (work in progress) will be useful instrument for a close review of the abovementioned fossil species of the genus (Garassino et al., work in progress).

Finally the specimens from the NW Pacific area previously assigned to $R$. americana need a close revision in order to clarify their real systematic position within the Raninidae sensu stricto.

\section{Acknowledgements}

Examination of types and figured specimens of the revised species was facilitated by numerous curators and collection managers. They provided images of the revised species, helping us to find and identify the old type series and the type specimens forgotten for a long time. They assisted us in the translation of several old German papers. We are indebted to all these curators and collection managers for their invaluable help. We particularly thank Martin Noose (Bayrische Staatssmmlung für Paläontologie und Geologie, Munich, Germany), Günter Schweigert (Staatliches Museum für Naturkunde, Stuttgart, Germany), Claire Mellish (Natural History Museum, London, United Kingdom), Sara Mansfield (California Academy of Sciences, San Francisco, United States); Maaike van Tooren (University of Technology, 
Delft, the Netherlands); Natasja den Ouden (Naturalis Biodiversity Center, Leiden, the Netherlands); Rodney M. Feldmann (Department of Geology, Kent State University, Kent, Ohio, United States); Piero Damarco (Museo Paleontologico “Giulio Maini”, Ovada, Italy).
Finally we thank Francisco J. Vega, Istituto de Geología, UNAM, Coyocán, (Mexico) and Torrey Nyborg, Department of Earth and Biological Sciences, Loma Linda University, Loma Linda, CA (USA), for careful review and criticism.

Tab. 1 - List of the Ranina fossil species as revised in this paper.

\begin{tabular}{|c|c|}
\hline Species doubtfully attributed to Ranina & \\
\hline ?Ranina americana Withers, 1924 & Washington State, USA (late Oligocene) \\
\hline ?Ranina berglundi Squires \& Demetrion, 1992 & Baja California Sur, Mexico (early Eocene) \\
\hline ?Ranina bouilleana A. Milne Edwards, 1872 & $\begin{array}{l}\text { Pyrénées Atlantiques, France (early Oligocene); } \\
\text { NE Italy (?early Oligocene) }\end{array}$ \\
\hline ?Ranina brevispina Lörenthey, 1898 & Algeria (Miocene, Langhian) \\
\hline ?Ranina granulosa A. Milne Edwards, 1872 & Gironde, France (Eocene-?Oligocene) \\
\hline ?Ranina griesbachi Noetling, 1897 & Pakistan (Late Cretaceous, Maastrichtian) \\
\hline ?Ranina haszlinskyi Reuss, 1859 & Radatice, Slovakia (early Oligocene) \\
\hline ?Ranina libyca (Van Straelen, 1935) & Egypt (Paleocene, Danian) \\
\hline ?Ranina molengraaffi Van Straelen, 1924 & Borneo (Miocene) \\
\hline ?Ranina oblonga (von Münster, 1840) & Germany (Oligocene) \\
\hline ?Ranina ornata De Angeli \& Beschin, 2011 & NE Italy (middle Eocene, Lutetian) \\
\hline ?Ranina speciosa (von Münster, 1840) & $\begin{array}{l}\text { NE Germany (Oligocene) } \\
\text { N Italy (late Oligocene-Miocene) }\end{array}$ \\
\hline Ranina nomina dubia & \\
\hline Ranina elegans (Rathbun, 1945) & Fiji (Miocene) \\
\hline Ranina hirsuta Schafhäutl, 1863 & S Germany (middle Eocene) \\
\hline Ranina lamiensis Rathbun, 1945 & Vitilevu Island, Fiji (Neogene) \\
\hline Ranina tejoniana Rathbun, 1926 & California, USA (Paleogene, Eocene series) \\
\hline Species attributed to other raninid genus & \\
\hline Lophoranina bavarica (Ebert, 1887) n. comb. & S Germany (Eocene) \\
\hline Lophoranina fabri (Schafhäutl, 1863) n. comb. & S Germany (middle Eocene) \\
\hline Lophoranina helii (Schafhäutl, 1863) n. comb. & S Germany (middle Eocene) \\
\hline Species attributed to other crustacean families & \\
\hline Calappa cuspidata (Guppy, 1909) n. comb. & Trinidad Island, Antilles (early Miocene) \\
\hline Doubtful species of Decapoda & \\
\hline Ranina burleighensis Holland in Holland \& Cvancara, 1958 & North Dakota, USA (Paleocene) \\
\hline Possible valid species of Ranina & \\
\hline Ranina palmea E. Sismonda, 1846 & N Italy (middle Miocene, Serravallian) \\
\hline Ranina pellattieroi De Angeli \& Beschin, 2011 & N Italy (early Miocene) \\
\hline Ranina propinqua Ristori, 1891 & $\begin{array}{l}\text { Central Italy (early Pleistocene, Gelasian-Calabrian); } \\
\text { S Italy (late Pleistocene, Tirrenian) }\end{array}$ \\
\hline Ranina ranina (Linnaeus, 1758) & Ryukyu Island, Japan (late Pleistocene) \\
\hline
\end{tabular}




\section{REFERENCES}

Addicott W.O., 1976 - Molluscan paleontology of the lower Miocene Clallam Formation, northwestern Washington. U.S. Geological Survey Professional Paper, 976: 1-44.

Ahyong S.T., Lai J.C.Y., Sharkey D., Colgan D.J. \& Ng P.K.L., 2007 - Phylogenetics of the brachyuran crabs (Crustacea: Decapoda) part 1: the status of Podotremata based on small subunit nuclear ribosomal RNA. Molecular Phylogenetics and Evolution, 45: 576-586.

Allasinaz A., 1987 - Brachyura Decapoda oligocenici (Rupeliano) del Bacino Ligure Piemontese. Bollettino del Museo regionale di Scienze naturali di Torino, 5 (2): 509-566.

Arnold R., 1906 - Geologic reconnaissance of the coast of the Olympic Peninsula. Geological Society of America Bulletin, 17, 1-461.

Baldanza A., Bizzarri R., Famiani F., Pasini G., Garassino A. \& De Angeli A., 2014 - Early Pleistocene shallow marine decapod crustaceans fauna from Fabro Scalo (western Umbria, central Italy): taxonomic inferences and palaeoenvironmental reconstruction. Neues Jahrbuch für Geologie und Paläontologie, Abhandlungen, 271 (3): 261-283.

Bittner A., 1875 - Die Brachyuren des Vicentinischen Tertiärgebinges. Denkschriffen der Kaiserlichen Akademie der Wissenscheften in Wien, 34: 63-106.

Bittner A., 1883 - Neue Beiträge zur Kenntniss der Brachyuren-Fauna des Alttertiärs von Vicenza und Verona. Denkschriffen der Kaiserlichen Akademie der Wissenscheften in Wien, 46: 299-316.

Boussac J., 1911 - Études stratigraphiques et paléontologiques sur le Nummulitique de Biarritz. Annales Hébert. Annales de Stratigraphie et de Paléontologie du Laboratoire de Géologie de la Faculté des Sciences de l'Univeristé de Paris, 5: 1-96.

Collins J.S.H., Portell R.W. \& Donovan S.K., 2009 - Decapod crustaceans from the Neogene of the Caribbean: diversity, distribution and prospectus. Scripta Geologica, 138: 55-111.

De Angeli A. \& Beschin C., 2011 - Il genere Ranina Lamarck, 1801 (Crustacea, Decapoda, Raninidae) nel Terziario del Vicentino, con descrizione di due nuove specie. Studi e Ricerche - Associazione Amici del Museo-Museo Civico "G. Zannato", 18: 11-20.

De Angeli A., Dall'Igna G.L. \& Ceccon L., 2009 - Segnalazione di Ranina sp. (Decapoda, Brachyura, Raninidae) dell'Eocene superiore di Monte Malo (Vicenza, Italia settentrionale). Lavori - Società Veneziana di Scienze Naturali, 34: 119-122.

Ebert T., 1887 - Beitrag zur Kenntniss der tertiären Decapoden Deutschlands. Jahrbuch der königlich preussischen geologischen Landesanstalt, 1886: 262-271.

Ebert T., 1889 - Die Raninen des Kressenbergs. Jahrbuch der königlich preussischen geologischen Landesanstalt, 1888: 129-133.

Fabiani R., 1910 - Sulle specie di Ranina finora note ed in particolare sulla Ranina Aldrovandii. Atti della Accademia Scientifica Veneto-Trentino-Istriana, 3 (3): 85-102.
Famiani F., Baldanza A., Bizzarri R., De Angeli A., Garassino A. \& Pasini G., 2015 - New report of Ranina propinqua Ristori, 1891 (Brachyura, Raninidae) from central Italy. Neues Jahrbuch für Geologie und Paläontologie, Abhandlungen, 275 (3): 337-346.

Feldmann R.M. \& Schweitzer C.E., 2007 - Sexual dimorphism in extinct and extant Raninidae (Decapoda: Brachyura). Annals of Carnegie Museum, 76: 39-52.

Filo I. \& Stráňová Z., 1996 - Tomasovske vrstvy - nova litostratigraficka jednotka podtatranskej skupiny. Geologicke prace, 102: 41-49.

Glaessner M.F., 1929 - Crustacea Decapoda. In: Fossilium Catalogus. I: Animalia. Pompeckj F.J. (ed.). $W$. Junk, Berlin, 41: 1-464.

Guinot D., 1993 - Données nouvelles sur les Raninoidea De Haan, 1841 (Crustacea Decapoda Brachyura Podotremata). Comptes Rendus de l'Académie des Sciences, Sciences de la vie, 316 (3): 1324-1331.

Guppy R.L.J., 1909 - Preliminary notice of a discovery of fossils in the Tamana District, Trinidad. Bulletin of the Agriculture Department Trinidad, 1909: 5-6.

Guppy R.L.J., 1911 - On a collection of fossils from Springvale near Couva, Trinidad. Papers Agriculture Society Trinidad and Tobago, 440: 1-15.

Holland F.D. Jr. \& Cvancara A.M., 1958 - Crabs from the Cannonbal Formation (Paleocene) of North Dakota. Journal of Paleontology, 32 (3): 495-5.

Hyžný M., 2011 - Synopsis of fossil decapod crustaceans from Slovakia (Western Carpathians). Neues Jahrbuch für Geologie und Paläontologie, Abhandlungen, 260 (2): 165-171.

Karasawa H., Schweitzer C.E. \& Feldmann R.M., 2011 Phylogenetic analysis and revised classification of podotrematous brachyura (Decapoda) including extinct and extant families. Journal of Crustacean Biology, 31 (3): 523-565.

Karasawa H., Schweitzer C.E., Feldmann R.M. \& Luque J., 2014 - Phylogeny and classification of Raninoida (Decapoda: Brachyura). Journal of Crustacean Biology, 34 (2): 216-272.

Lőrenthey E., 1898a - Beiträge zur Decapodenfauna des ungarischen Tertiärs. Természetrajzi Füzetek, 21: $1-133$.

Lörenthey E., 1898b - Über die Brachyuren der palaeontologischen sammlung des Bayrischen Staates. Természetrajzi Füzetek, 21: 134-152.

Lőrenthey E. \& Beurlen K., 1929 - Die Fossilen Dekapoden der Länder der Ungarischen Krone. Geologica Hungarica (Palaeontologica), 3: 1-421.

Milne Edwards A., 1872 - Note sur quelques crustacés fossiles appartenant aux genres Ranina et Galenopsis. Annales des Sciences géologiques, 3: 1-11.

Münster G. von, 1840 - Ueber ein neues Brachyurengenus in der tertiären Formationen des nordwestlichen Deutschlands. Beiträge zur Petrefactenkunde, 3: $1-24$.

Noetling F., 1897 - Fauna of the Upper Cretaceous (Maëstrichtien) beds of the Mari Hills. Memoirs of the Geological Survey of India, Palaeontologica Indica, 1 (3): 1-79. 
Oppenheim P., 1903 - Ueber die Ueberkippung von S. Orso, das Tertiär des Tretto und Fauna wie Stellung der Schioschichten. Zeitschrift der Deutschen Geologischen Gesellschaft, 55: 98-235.

Pasini G. \& Garassino A., 2017 - A new raninoid crab (Crustacea, Decapoda, Raninidae) from the early Oligocene (late Rupelian) of Italy: systematics and palaeogeographic evidences. Natural History Sciences Atti della Società italiana di Scienze naturali e del Museo civico di Storia naturale in Milano, 4 (1): 87-96. doi: 10.4081/nhs.2017.323

Prothero D.R. \& Burns C., 2001 - Magnetic stratigraphy and tectonic rotation of the upper Oligocene-?lower Miocene (type Pillarian stage) Clallam Formation, Clallam County, Washington. Pacific Section SEPM, 91: 234-241.

Prothero D.R. \& Nesbitt E.A., 2008 - Paleomagentism and tectonic rotation of the Restoration Point Member of the Blakeley Formation (Type Blakeley Stage), Bainbridge Island, Washington, and the Pacific Coast Oligocene-Miocene Boundary. In: Neogene Mammals. Lucas S.G., Morgan G.S., Spielmann J.A. \& Prothero D.R., (eds.). New Mexico Museum of Natural History and Science Bulletin, 44: 315-322.

Rathbun M.J., 1919 - West Indian Tertiary decapod crustaceans. Carnegie Institute of Washington Publication, 291: 159-184.

Rathbun M.J., 1926 - The fossil stalk-eyed Crustacea of the Pacific slope of North America. Bulletin of the United States National Museum, 138: 1-155.

Rathbun M.J., 1934 - Fossil decapod crustaceans from Vitilevu, Fiji. Bernice P. Bishop Musem Bulletin, 119: 238-241.

Rathbun M.J., 1945 - Decapod Crustacea. In: Geology of Lau, Fiji. Ladd H.S. \& Hoffmeister J.E. (eds.). Bernice Pauahi Bishop Museum Bulletin, 181: 373-383.

Reuss A., 1859 - Zur Kenntniss fossiler Krabben. Denkschriften der kaiserlichen Akademie der Wissenschaften in Wien, 17: 1-90.

Ristori G., 1889 - Crostacei Piemontesi del Miocene Inferiore. Bollettino della Società Geologica Italiana, 7: 397-413.

Schafhäutl K.F.E., 1863 - Süd-Bayerns Lethaea Geognostica. Der Kressnberg und die südlich von ihm gelegenen Hochalpen geognostich betrachtet in ihren Petrefakten. Leopold Voss, Leipzig.

Schweitzer C.E., 2003 - Utility of proxy characters for classification of fossils: an example from the fossil Xanthoidea (Crustacea: Decapoda: Brachyura). Journal of Paleontology, 77 (6): 1107-1128.

Schweitzer C.E, Feldmann R.M., Garassino A., Karasawa H. \& Schweigert G., 2010 - Systematic list of fossil decapod crustacean species. Crustaceana Monographs, 10: 1-222.

Schweitzer C.E., Feldmann R.M., González-Barba G. \& Cosovic V., 2006 - New Decapoda (Anomura, Brachyura) from the Eocene Bateque and Tepetate Formations, Baja California Sur, México. Bulletin of the Mizunami Fossil Museum, 33: 26-45.

Squires R.L. \& Demetrion R.A., 1992 - Paleontology of the Eocene Bateque Formation, Baja California Sur,
Mexico. Los Angeles County Museum, Contributions in Science, 434: 1-55.

Tucker A.B., 1988 - Systematics of the Raninidae (Crustacea: Decapoda: Brachyura), with accounts of three new genera and two new species. Proceedings of the Biological Society of Washington, 111: 320-371.

Van Bakel W.M., Guinot D., Artal P., Fraaije R.H.B. \& Jagt J.W.M., 2012 - A revision of the Palaeocorystoidea and the phylogeny of raninoidian crabs (Crustacea, Decapoda, Brachyura, Podotremata). Zootaxa, 3215: 1-216.

Van Straelen V., 1924 - Description de Crustacés décapodes nouveaux des terrains tertiares de Borneo. $\mathrm{Ko}$ ninklijke Akademie van Wetenschappen te Amsterdam, Proceedings, 26: 489-492.

Van Straelen V., 1935 - Sur un raninide nouveau du Danien de la Libye. Bulletin de l'Institut d'Égypte, 17: 113-115.

Vega F.J., Nyborg T., Coutiño M.A. \& Hernández-Monzón O., 2008 - Review and additions to the Eocene decapod Crustacea from Chiapas, Mexico. Bulletin of the Mizunami Fossil Museum, 34: 51-71.

Waugh D.A., Feldmann R.M. \& Schweitzer C.E., 2009 Systematic evaluation of raninid cuticle microstructure. Bulletin of the Mizunami Fossil Museum, 35: 1541.

Whiters T.H., 1924 - Some Decapod Crustaceans (Callianassa and Ranina) from the Oligocene of Washington, State, U.S.A. The Annals and Magazine of Natural History, 14 (9): 121-127. 